\title{
1 Effects of water, depth and temperature on 2 partial melting of mantle-wedge fluxed by 3 hydrous sediment-melt in subduction zones
}

5 Ananya Mallik ${ }^{1,2 *}$

6 Rajdeep Dasgupta ${ }^{1}$

7 Kyusei Tsuno ${ }^{1}$

8 Jared Nelson ${ }^{1,3}$

$10{ }^{1}$ Rice University; Department of Earth Science, 6100 Main Street, MS 126, Houston, TX 77005, USA

$11 \quad{ }^{2}$ Bayerisches Geoinstitut; Universität Bayreuth, 95440 Bayreuth, Germany

$12{ }^{3}$ Texas A\&M University; Department of Physics and Astronomy, 4242 TAMU, College Station, TX

1377843 , USA

14 *Corresponding author e-mail and current address: Ananya.Mallik@uni-bayreuth.de. Bayerisches

15 Geoinstitut; Universität Bayreuth, 95440 Bayreuth, Germany. Telephone: +49-921-55-3743, Fax: +49-

$16 \quad 921-55-3769$

17 Abstract

This study investigates the partial melting of variable bulk $\mathrm{H}_{2} \mathrm{O}$-bearing parcels of mantle-wedge

19 hybridized by partial melt derived from subducted metapelites, at pressure-temperature $(P-T)$ conditions

20 applicable to hotter core of the mantle beneath volcanic arcs. Experiments are performed on mixtures of

$2125 \%$ sediment-melt with $75 \%$ fertile peridotite, from $1200-1300{ }^{\circ} \mathrm{C}$, at 2 and $3 \mathrm{GPa}$, with bulk $\mathrm{H}_{2} \mathrm{O}$

22 concentrations of 4 and 6 wt.\%. Combining the results from these experiments with previous 
23 experiments containing 2 wt.\% bulk $\mathrm{H}_{2} \mathrm{O}$ (Mallik et al., 2015), it is observed that all melt compositions,

24 except those produced in the lowest bulk $\mathrm{H}_{2} \mathrm{O}$ experiments at $3 \mathrm{GPa}$, are saturated with olivine and

25 orthopyroxene. Also, higher bulk $\mathrm{H}_{2} \mathrm{O}$ concentration increases melt fraction at the same $P-T$ condition,

26 and causes exhaustion of garnet, phlogopite and clinopyroxene at lower temperatures, for a given

27 pressure. The activity coefficient of silica $\left(\Upsilon_{\mathrm{SiO} 2}\right)$ for olivine-orthopyroxene saturated melt compositions

28 (where the activity of silica, $a_{\mathrm{SiO} 2}$, is buffered by the reaction olivine $+\mathrm{SiO}_{2}=$ orthopyroxene) from this

29 study and from mantle melting studies in the literature are calculated. In melt compositions generated at

$302 \mathrm{GPa}$ or shallower, with increasing $\mathrm{H}_{2} \mathrm{O}$ concentration, $\Upsilon_{\mathrm{SiO} 2}$ increases from $<1$ to $\sim 1$, indicating a

31 transition from non-ideal mixing as $\mathrm{OH}^{-}$in the melt $\left(\Upsilon_{\mathrm{SiO} 2}<1\right)$ to ideal mixing as molecular $\mathrm{H}_{2} \mathrm{O}\left(\Upsilon_{\mathrm{SiO} 2}\right.$

$32 \sim 1)$. At pressures $>2 \mathrm{GPa}, \Upsilon_{\mathrm{SiO} 2}>1$ at higher $\mathrm{H}_{2} \mathrm{O}$ concentrations in the melt, indicate requirement of

33 excess energy to incorporate molecular $\mathrm{H}_{2} \mathrm{O}$ in the silicate melt structure, along with a preference for

34 bridging species and polyhedral edge decorations. With vapor saturation in the presence of melt, $\Upsilon_{\mathrm{SiO} 2}$

35 decreases indicating approach towards ideal mixing of $\mathrm{H}_{2} \mathrm{O}$ in silicate melt. For similar $\mathrm{H}_{2} \mathrm{O}$

36 concentrations in the melt, $\Upsilon_{\mathrm{SiO} 2}$ for olivine-orthopyroxene saturated melts at $3 \mathrm{GPa}$ is higher than melts

37 at $2 \mathrm{GPa}$ or shallower. This results in melts generated at $3 \mathrm{GPa}$ being more silica-poor than melts at 2

38 GPa. Thus, variable bulk $\mathrm{H}_{2} \mathrm{O}$ and pressure of melt generation results in the partial melts from this study

39 varying in composition from phonotephrite to basaltic andesite at $2 \mathrm{GPa}$ and foidite/phonotephrite to

40 basalt at $3 \mathrm{GPa}$, thus forming a spectrum of arc lavas. Modeling suggests that the trace element patterns

41 of sediment-melt are unaffected by the process of hybridization within the hotter core of the mantle-

42 wedge. $\mathrm{K}_{2} \mathrm{O} / \mathrm{H}_{2} \mathrm{O}$ and $\mathrm{H}_{2} \mathrm{O} / \mathrm{Ce}$ ratios of the sediment-melts are unaffected, within error, by the process of

43 hybridization of the mantle-wedge. This implies that thermometers based on $\mathrm{K}_{2} \mathrm{O} / \mathrm{H}_{2} \mathrm{O}$ and $\mathrm{H}_{2} \mathrm{O} / \mathrm{Ce}$

44 ratios of arc lavas may be used to estimate slab-top temperatures when a) sediment-melt from the slab

45 reaches the hotter core of the mantle-wedge by focused flow b) sediment-melt freezes in the overlying 
mantle at the slab-mantle interface and the hybridized package rises as a mélange diapir and partially

47 melts at the hotter core of the mantle-wedge. Based on the results from this study and previous studies,

48 both channelized and porous flow of sediment-melt/fluid through the sub-arc mantle can explain

49 geochemical signatures of arc lavas under specific geodynamic scenarios of fluid/melt fluxing,

50 hybridization, and subsequent mantle melting.

\section{$51 \quad$ 1. Introduction}

Arc lavas have typical geochemical signatures such as enrichment in Large Ion Lithophile

Elements, $\mathrm{H}_{2} \mathrm{O}$, $\mathrm{U}$ and Th due to input from subducted slab in their source. The slab component involved maybe aqueous fluid and/or melt from subducted sediments and altered oceanic crust. The involvement of subducted sediments in the formation of arc lavas has been demonstrated by the presence of the cosmogenic isotope ${ }^{10} \mathrm{Be}$ (e.g. Morris and Terra, 1989) in arc lavas (that suggests addition of recent surface material), and with similarity in trace element patterns and ratios between arc lavas and corresponding subducted sediments . Although geochemical evidence does indicate sediments being involved in the formation of arc lavas, the process by which their geochemical signature is transferred to arc magmas is not well understood. The sedimentary contribution in cold subduction zones is likely in

61 the form of aqueous fluids, whereas, in intermediate to hot subduction zones, it is likely in the form of

62 hydrous melts (Hermann and Rubatto, 2009). The melt compositions of metapelitic sediments are

63 siliceous and may contain variable water contents in subduction zone conditions (e.g. Auzanneau, et al,

64 2006, Hermann and Spandler, 2008, Johnson and Plank, 2000, Thomsen and Schmidt, 2008, Tsuno and

65 Dasgupta, 2012); hence, they metasomatize the mantle-wedge to form orthopyroxene at the expense of

66 olivine \pm hydrous minerals such as phlogopite and amphibole. Although the process of hybridization of

67 sediment-melt with mantle-wedge peridotite has been studied, there remain the following outstanding questions on melting of the arc source, which require further investigation. 
a) How do pressure $(P)$, temperature $(T)$, and importantly bulk $\mathrm{H}_{2} \mathrm{O}$ content of the zone of production of primitive arc magma as well as the flux of sediment-melt to peridotite affect the phase equilibria of hybridization? In the study by Mallik et al. (2015), the authors had studied the phase equilibria of hybridization of sediment-melt with mantle-wedge peridotite containing a fixed $\mathrm{H}_{2} \mathrm{O}$ content of $2 \mathrm{wt} . \%$ in the bulk sediment-melt+peridotite mixture. They had found that such a process of hybridization produced ultrapotassic leucitites, similar to ultrapotassic lavas from several post collisional settings and active arcs. However, what effect does bulk $\mathrm{H}_{2} \mathrm{O}$ content have on the magmas derived from sediment-melt fluxed mantle-wedge and can it, along with $P$ and $T$, explain wider range of alkalic to tholeiitic arc lavas remain unknown.

b) $\mathrm{H}_{2} \mathrm{O}$ being the most abundant volatile species in arc magmas, what effect does it have on the melting systematics of the hybridized arc source? Hydrous partial melts of spinel peridotite (pressure $\leq 2 \mathrm{GPa}$ ) are andesitic due to expansion of olivine stability with respect to dry systems (Kushiro, 1972; Nicholls and Ringwood, 1973), whereas, hydrous partial melts of garnet peridotite are more silica-poor than their anhydrous partial melt counterparts . Why is there a difference of the influence of $\mathrm{H}_{2} \mathrm{O}$ on mantle melting with pressure?

c) The presence of slab-input in the source of primary arc lavas are inferred based on geochemical tracers. In fact, $\mathrm{K}_{2} \mathrm{O} / \mathrm{H}_{2} \mathrm{O}$ and $\mathrm{H}_{2} \mathrm{O} / \mathrm{Ce}$ ratios of arc lavas have been used as thermometers to determine slab-top temperatures for various arcs (Cooper et al., 2012; Hermann and Spandler, 2008; Plank et al., 2009). If the primary arc lavas are generated by reactive infiltration of slabderived component through the mantle-wedge, or, by hybridization of the slab-component with the mantle within a mélange, the geochemical tracers can be tied back to slab-derived components or used to estimate slab-top temperatures either, if they are unaffected by the process of hybridization, or, if the effect of the process of hybridization on the geochemical 
tracers are known. Hence, it is important to investigate the effect of trace element systematics of slab components on the process of metasomatism/hybridization of the mantle-wedge.

d) A recent study by Pirard and Hermann (2015) investigated the hybridization of sediment-melt with the mantle at the slab-mantle interface via porous and channelized flow. However, it needs to be investigated how the melt compositions produced by hybridization at the slab-mantle interface continue to affect the composition of equilibrated magma at the hotter mantle-wedge core. arc fertile mantle, at a $P-T$ range and variable bulk $\mathrm{H}_{2} \mathrm{O}$ concentrations, but with fixed sediment-

In this study, we investigate the phase equilibria of a mixture of sediment-melt and submelt:mantle ratio. We simulate the reactive infiltration of a mass of sediment-melt through the mantle-wedge, and explore the closed system partial melting behavior of the parcel of mantle hybridized by the sediment-melt, similar to that explored by Mallik and Dasgupta (2015) and Pirard and Hermann (2015). Experiments of Mallik and Dasgupta (2015) were done with a fixed water content. Here we explore the phase equilibria of similar reactive process but focus on the effect of variable $\mathrm{H}_{2} \mathrm{O}$ on the partial melt chemistry and melting reactions. In particular, we explore how variable water content affects the silica activity and other major element composition of magmas generated from sediment-melt infiltrated peridotite. We also model the trace element concentration of the partial melts using the available mineral-melt partition coefficients and the mineral modes from our experiments. We demonstrate that the trace element signatures of slab-derived sediment-melt is not significantly affected by a) focused flow of sediment-melt through the mantle-wedge followed by metasomatism at the hotter core of the wedge, b) porous flow hybridization and complete freezing-in of sediment-melt at the slabmantle interface, followed by diapiric rise of the hybridized package and subsequent partial 
melting at the hotter core of the mantle-wedge. We also show that a range of partial melt compositions with similar major and trace element signatures to those of near-primary arc magmas can be produced by hydrous partial melting of sediment-melt fluxed fertile mantlewedge.

\section{Methods}

\section{$121 \quad 2.1 \quad$ Starting materials}

The sediment-melt, in this study, is similar in major elements to the average composition of 123 partial melts of Global Subducting Sediment or GLOSS (Plank and Langmuir, 1998) generated at 3.5 $124 \mathrm{GPa}, 900-950{ }^{\circ} \mathrm{C}$ in the study by Hermann and Spandler (2008). Given the diversity of sediment 125 compositions at trenches worldwide (Plank and Langmuir, 1998) and sediment partial melt compositions 126 generated at sub-arc $P-T$ conditions (e.g., Grassi and Schmidt, 2011; Hermann and Green, 2001; 127 Hermann and Spandler, 2008; Mann and Schmidt, 2015; Schmidt, 2015; Schmidt et al., 2004; Thomsen 128 and Schmidt, 2008; Tsuno and Dasgupta, 2011, 2012), the sediment-melt composition chosen in this 129 study is one of the several likely compositions to be applicable for subduction zones. The peridotite, in 130 this study, is similar in composition to the lherzolite KLB-1 reported by Takahashi (1986) and Davis et 131 al. (2009) . The starting materials are mixtures of $25 \%$ sediment-melt and $75 \%$ peridotite, and on a 132 volatile-free basis, are similar to the starting material used by Mallik et al. (2015) . The bulk water 133 contents of the sediment-melt + peridotite mixture used in this study are 4 wt.\% and 6 wt.\% (Table 1). In 134 other words, the corresponding sediment-melt water contents are 16 and 24 wt.\%. Experiments with 1.8 135 wt.\% bulk water (7.2 wt.\% $\mathrm{H}_{2} \mathrm{O}$ in sediment-melt) have been reported in Mallik et al. (2015) . The 136 sediment-melt and peridotite mixtures with 4 wt.\% and 6 wt. $\% \mathrm{H}_{2} \mathrm{O}$ were synthesized following mixing, 137 drying, and reduction procedures as outlined in Mallik et al. (2015). 


\subsection{Experimental technique}

The starting materials ( 4 wt.\% and 6 wt.\% bulk water) were packed in $\mathrm{Au}_{75}-\mathrm{Pd}_{25}$ capsules with

142 space between the two capsules were packed with the same starting material, in order to minimize

143 hydrogen loss from the starting material. This double capsule geometry has been modified from Kagi et

144 al. (2005). The inner and outer capsules were sealed by coning. Welding by a graphite arc welder was

145 avoided in order to minimize carbon contamination in the starting material (Mallik et al., 2015).

146 The experiments were performed using piston-cylinder apparatus in the Experimental Petrology

147 Laboratory at Rice University at pressures of 2 and $3 \mathrm{GPa}$, with temperatures ranging from 1200 to 1300

$148{ }^{\circ} \mathrm{C}$, which correspond to $P-T$ conditions applicable for sub-arc mantle-wedge (England and Katz, 2010;

149 Syracuse et al., 2010) (Table 2). The experimental assembly, procedure, and relevant calibration are

150 reported in Tsuno and Dasgupta (2011) . Experiments were run for 38-93 hours, with lower $\mathrm{H}_{2} \mathrm{O}-$

151 bearing experiments towards the lower end of the temperature range run for longer durations. After the

152 assembly was extracted from the piston-cylinder, the capsules were cut in half longitudinally using a

153 wire-saw (with a wire of diameter 60 micrometer) and impregnated with epoxy under vacuum to

154 preserve the delicate hydrous quench from the melt pool as well as fragile phlogopite. The capsules were

155 polished under water, with the sample being exposed first under 1200 grit silicon carbide paper,

156 followed by polishing on lapping film impregnated with 3 micrometer alumina and velvet cloth with 0.3

157 micrometer alumina slurry. It was not possible to preserve the quench matter in the melt pool while

158 ensuring a good polish for the minerals simultaneously. Therefore one half of the capsule was polished

159 minimally to expose the delicate quench matter for compositional analysis, whereas, the minerals were

160 polished well in the second half. 


\subsection{Analysis of run products}

The polished samples were imaged using the Scanning Electron Microscope FEI Quanta 400

164 FEG ESEM at Rice University and compositional analyses for all the phases in the inner and outer

165 capsules were performed using the Cameca SX 100 Electron Microprobe Analyzer (EMPA) at Johnson 166 Space Center, Houston and Inductively Coupled Plasma Mass Spectrometer (ICPMS) ThermoFinnigan 167 Element 2 coupled with a $213 \mathrm{~nm}$ laser ablation system (New-Wave) at Rice University. There is no 168 compositional difference observed between phases in the inner and outer capsules, within error. Major and minor elements for all the phases were measured at $15 \mathrm{kV}$ using EMPA. Olivine, 170 orthopyroxene and garnet were measured using $20 \mathrm{nA}$ electron beam of diameter 1 micrometer, 171 phlogopite was measured at $5 \mathrm{nA}$ using a 5 micrometer beam, whereas, the quenched melt pool was 172 measured using defocused 20-50 micrometer beam at $10 \mathrm{nA}$. The quenched pool, being coarse grained 173 and very heterogeneous in composition and texture, was analyzed using wide defocused beam to analyze 174 as large a spot as possible. Also, $>60$ points were analyzed for melt pools in each sample to obtain 175 robust average melt compositions. Counting times for all the elements were 20 seconds at the peak and 17610 seconds on each background. The standards used were NIST glass K411 ( $\mathrm{Si}, \mathrm{Ca}, \mathrm{Fe}, \mathrm{Mg}$ ), diopside 177 ( $\mathrm{Si}, \mathrm{Ca}, \mathrm{Mg}$ ), fayalite (Si, Fe), almandine ( $\mathrm{Si}, \mathrm{Al}, \mathrm{Fe})$, pyrope (Si, Al, Mg), andradite (Ca), oligoclase 178 (Al, Na), orthoclase $(\mathrm{K})$, rutile $(\mathrm{Ti})$, chromite $(\mathrm{Cr})$, apatite $(\mathrm{P})$ and rhodochrosite $(\mathrm{Mn})$. Concentrations of major and minor elements of quenched pool for all the samples, except G358

180 and G381, were also analyzed using LA-ICPMS to crosscheck between the compositions determined by 181 the two methods. EMPA is a non-destructive method and LA-ICPMS is destructive. The principal 182 advantage of using LA-ICPMS over EMPA is the higher depth of sampling of the former $(\sim 10 \mu \mathrm{m}$, 183 Gonzalez et al., 2002) as compared to the latter ( 1 $\mu \mathrm{m}$, Goldstein et al., 2012). The instrument was 
184 tuned using USGS glass standard BHVO2g on La $(15 \mu \mathrm{g} / \mathrm{g})$ with a beam size of $55 \mu \mathrm{m}$, repetition rate 185 of $10 \mathrm{~Hz}$ and fluence of $12-16 \mathrm{~J} / \mathrm{cm}^{2}$, in order to reach a sensitivity of $250,000-350,000 \mathrm{cps}$. The 186 USGS glass standards BHVO2g, BCR2g and BIR1g were analyzed as external standards before and at 187 the end of the sample analyses session. The external standards were reproduced within $1-9 \%$. The data 188 acquisition time for each spot was 2 minutes 38 seconds, with $\sim 30$ seconds for background and the 189 remaining time for ablation. Individual spots were analyzed in the quenched pool, with diameter varying 190 from $80-110 \mu \mathrm{m}, 10 \mathrm{~Hz}$ repetition rate and $\sim 11 \mathrm{~J} / \mathrm{cm}^{2}$ fluence. The isotope ${ }^{44} \mathrm{Ca}$ was used as internal 191 standard for instrumental drift correction. The measurements were performed in medium resolution $(\mathrm{m} /$ $192 \Delta m=3000)$ and the oxide concentrations of the following isotopes were reported: ${ }^{30} \mathrm{Si},{ }^{49} \mathrm{Ti},{ }^{27} \mathrm{Al},{ }^{52} \mathrm{Cr}$, $193{ }^{57} \mathrm{Fe},{ }^{55} \mathrm{Mn},{ }^{25} \mathrm{Mg},{ }^{44} \mathrm{Ca},{ }^{23} \mathrm{Na},{ }^{39} \mathrm{~K},{ }^{31} \mathrm{P}$. Data reduction was performed using the Excel-Visual Basic 194 program from http://www.cintylee.org/\#/facilities/.

\section{Results}

\subsection{Texture and phase assemblage}

Melt (represented by quench) in the experiments pooled at the top of the inner capsule and on either sides of the outer capsule (Figure 1). The heterogeneous quench aggregate consists of coarse $(\sim 150 \mu \mathrm{m}$ long) and finer $(\sim \leq 50 \mu \mathrm{m}$ long) phlogopite-like radiating, acicular and dendritic grains with darker interstitial matter as well as bright Fe-rich pyroxene-like grains. Olivine grains are coarser $(\sim \geq$ $50 \mu \mathrm{m})$ than orthopyroxene $(\sim \leq 50 \mu \mathrm{m})$, with the olivine grains crystallized closest to the melt.

205 Table 2. Garnet, phlogopite and clinopyroxene are exhausted from the experiments at a lower temperature with increasing bulk water concentrations at both 2 and $3 \mathrm{GPa}$. The distinct differences in 
207 phase stability between 2 and $3 \mathrm{GPa}$ are: (a) Absence of olivine in the lowest bulk water samples at 3

$208 \mathrm{GPa}$ whereas olivine was present at all bulk water concentrations at $2 \mathrm{GPa}$, (b) Absence of garnet at 2

209 GPa whereas garnet was present at $3 \mathrm{GPa}$, (c) Phlogopite and clinopyroxene are absent in the sample at

210 lower temperatures at $2 \mathrm{GPa}$ as compared to $3 \mathrm{GPa}$, for a given bulk water concentration.

211 Phase proportions (including amount of melt) for each experiment were estimated by mass

212 balance using melt compositions from electron microprobe and LA-ICPMS, and mineral compositions

213 from electron microprobe (Table 2). The amount of melt produced in the experiments increases with

214 temperature at a given pressure and decreases with pressure at a given temperature (in agreement with

215 Mallik et al., 2015), the amount of melt also increases with increasing bulk $\mathrm{H}_{2} \mathrm{O}$ concentration at a

216 certain temperature and pressure (Figure 3, Supplementary Figure 1). For example, at $2 \mathrm{GPa}$ and 1200

$217{ }^{\circ} \mathrm{C}$, the melt fraction increases from $20 \pm 3$ to $47 \pm 1 \mathrm{wt} . \%$ for bulk $\mathrm{H}_{2} \mathrm{O}$ concentration of 2 to $6 \mathrm{wt} . \%$,

218 whereas, at $3 \mathrm{GPa}$ and $1250{ }^{\circ} \mathrm{C}$, the melt fraction increases from $18 \pm 3$ to $43 \pm 3 \mathrm{wt} . \%$ for a similar

219 increase in bulk $\mathrm{H}_{2} \mathrm{O}$ concentration. A similar trend is also observed for melt fractions estimated using 220 melt compositions obtained from LA-ICPMS (Supplementary Figure 1).

2223.2 Approach to chemical equilibrium, Fe-loss to capsule and determination of intrinsic oxygen 223 fugacity in the experiments

224 The experiments in this study have not been reversed but an approach to chemical equilibrium 225 can be demonstrated by: (a) homogeneity in composition of minerals from core to the rim (including 226 garnets), (b) systematic change in composition of melt and minerals as a function of temperature (Table 227 1, Supplementary Table 1), (c) olivine-melt and orthopyroxene-melt $\mathrm{Fe}^{2+}-\mathrm{Mg} \mathrm{K}_{\mathrm{D}}$ varies from 0.29-0.41 228 (for melt compositions determined by electron microprobe; Supplementary Table 1) and 0.19-0.39 (for 
melt compositions determined by LA-ICPMS; Supplementary Table 1), which lie within the range of

230 olivine/orthopyroxene-melt $\mathrm{Fe}^{2+}-\mathrm{Mg} \mathrm{K}$ D of previous studies based on hydrous mantle melting .

231 The relative amount of Fe-loss to the $\mathrm{Au}_{75} \mathrm{Pd}_{25}$ capsule was estimated by mass balance and 232 varied from $6 \pm 4$ to $33 \pm 19$. Except for run G375, the relative Fe-loss to the capsules in this study is 233 lower than the experiments performed using single $\mathrm{Au}_{75} \mathrm{Pd}_{25}$ or $\mathrm{Au}_{80} \mathrm{Pd}_{20}$ capsule in Mallik et al. (2015) 234 . The intrinsic $f \mathrm{O}_{2}$ of the experiments was measured using the oxybarometer of Barr and Grove (2010) 235 using the pressure and temperature of the experiments, Fe concentration of the capsule closest to the 236 sample and $\mathrm{FeO}^{*}$ concentration of melt. $f \mathrm{O}_{2}$ varied from $0.0 \pm 0.2$ to $-1.5 \pm 0.2 \log$ units with respect to 237 the FMQ buffer. The $f \mathrm{O}_{2}$ of the experiments agree with Mallik et al. (2015) and are similar to those 238 estimated for supra-subduction zone peridotites (Foley, 2011).

\subsection{Melt composition}

The melt compositions measured by both EMPA and LA-ICPMS are reported in Table 1 and are compared in Supplementary Figure 2. Overall, the melt compositions measured by the two methods are in agreement; the most distinct difference being up to $70 \%$ (relative) higher $\mathrm{K}_{2} \mathrm{O}$ concentration measured by LA-ICPMS over that measured by EMPA. This may be explained by the greater sampling volume of LA-ICPMS as compared to that of EMPA. Some of the K-rich phlogopite-like quench crystals were likely plucked off the top surface of the samples during polishing, resulting in lower $\mathrm{K}_{2} \mathrm{O}$ concentrations measured by EMPA. We have presented the major results from this study using both data from electron microprobe and LA-ICPMS and we find that there is no significant difference observed in terms of discussion between the two.

The melt compositional data obtained from LA-ICPMS (for experiments B307, B309, G376, 251 G377, G379, G380, G378, G374 and G375) and electron microprobe (for the remaining experiments) 
252 are discussed here (Figure 4). In case of partial melts generated from bulk compositions with 4 wt.\%

253 bulk $\mathrm{H}_{2} \mathrm{O}$, the melt compositions are more siliceous at $2 \mathrm{GPa}$ than at $3 \mathrm{GPa}$. At $2 \mathrm{GPa}$, with increasing 254 melt fraction from 0.30 to $0.53, \mathrm{SiO}_{2}$ and $\mathrm{MgO}$ concentrations increase from $47 \pm 1$ to $51 \pm 1 \mathrm{wt} . \%$ and $25514.5 \pm 0.7$ to $19 \pm 1$ wt. $\%$, respectively, whereas $\mathrm{Al}_{2} \mathrm{O}_{3}, \mathrm{CaO}, \mathrm{Na}_{2} \mathrm{O}$ and $\mathrm{K}_{2} \mathrm{O}$ concentrations decrease. $256 \mathrm{FeO}^{*}$ concentration varies from $5.2 \pm 0.2$ to $7.0 \pm 0.6 \mathrm{wt} . \%$ with increasing melting degree. At $3 \mathrm{GPa}$, 257 with increasing melt fraction from 0.24 to $0.35, \mathrm{SiO}_{2}$ and $\mathrm{MgO}$ concentrations increase from $41 \pm 2$ to $25842.7 \pm 0.6$ wt. $\%$ and $21 \pm 1$ to $22.4 \pm 0.4$ wt. $\%$, respectively. $\mathrm{Al}_{2} \mathrm{O}_{3}, \mathrm{CaO}, \mathrm{Na}_{2} \mathrm{O}$ and $\mathrm{K}_{2} \mathrm{O}$ concentrations 259 decrease, whereas $\mathrm{FeO}^{*}$ varies from $7.9 \pm 0.2$ to $8.1 \pm 0.2$ wt.\%.

260 In case of partial melts generated from bulk compositions with 6 wt.\% bulk $\mathrm{H}_{2} \mathrm{O}$, the melt 261 compositions are also more siliceous at $2 \mathrm{GPa}$ than at $3 \mathrm{GPa}$. At $2 \mathrm{GPa}$, with increasing melt fraction 262 from 47 to 58 wt. $\%, \mathrm{SiO}_{2}$ and $\mathrm{FeO} *$ concentrations vary around $50 \pm 2$ wt. $\%$ and $7.5 \pm 0.4$ to $7.2 \pm 0.4$ 263 wt.\%, respectively. $\mathrm{Al}_{2} \mathrm{O}_{3}, \mathrm{CaO}, \mathrm{Na}_{2} \mathrm{O}$ and $\mathrm{K}_{2} \mathrm{O}$ display a decrease, whereas, $\mathrm{MgO}$ concentration 264 increases with increasing degree of partial melting. At $3 \mathrm{GPa}$, with melt fraction increasing from 21 to 26546 wt. $\%, \mathrm{SiO}_{2}$ and $\mathrm{MgO}$ concentrations increase from $44 \pm 4$ to $46.3 \pm 0.8$ wt.\%, whereas, $\mathrm{Al}_{2} \mathrm{O}_{3}, \mathrm{CaO}$, $266 \mathrm{Na}_{2} \mathrm{O}$ and $\mathrm{K}_{2} \mathrm{O}$ concentrations decrease. $\mathrm{FeO} *$ varies from $6 \pm 1$ to $8.0 \pm 0.8$ wt.\%.

268 4. Discussion

$2694.1 \quad$ Effect of variable water on melting systematics of sediment-melt + peridotite and peridotite 270 The partial melts from this study and Mallik et al. (2015) range in composition from 271 phonotephrite to basaltic andesite at $2 \mathrm{GPa}$ and foidite/phonotephrite to basalt at $3 \mathrm{GPa}$ (Figure 5). The 272 melts generated at $2 \mathrm{GPa}$ are more siliceous as compared to those at $3 \mathrm{GPa}$, for the same bulk $\mathrm{H}_{2} \mathrm{O}$ 273 concentration. The reason why melt compositions produced at $3 \mathrm{GPa}$ are more silica-poor than melt 274 compositions produced at $2 \mathrm{GPa}$ is discussed in the next section. Total alkali concentration of the melt 
275 compositions depend on the degree of partial melting, bulk $\mathrm{H}_{2} \mathrm{O}$ concentration and depth of melting. At 276 lower degrees of partial melting (hence, lower temperature), presence of phlogopite in the residue 277 buffers the $\mathrm{K}_{2} \mathrm{O}$ content of the melt from 5-8 wt.\%, subsequently decreasing as phlogopite is exhausted 278 from the residue. Phlogopite is exhausted at a lower temperature with higher bulk $\mathrm{H}_{2} \mathrm{O}$ concentration; 279 hence, at the same $P-T$ of melting, lower $\mathrm{H}_{2} \mathrm{O}$-bearing assemblages produce higher $\mathrm{K}_{2} \mathrm{O}$ concentrations. 280 In addition, higher pressure stabilizes phlogopite to a higher temperature due to lower degree of melting 281 at higher pressure at a constant temperature. $\mathrm{Na}_{2} \mathrm{O}$ is incompatible in the residual minerals; hence, $\mathrm{Na}_{2} \mathrm{O}$ 282 concentration decreases with higher degree of melting. Therefore, a variety of primary arc lavas from 283 siliceous to more silica-undersaturated compositions, with a variety of alkali concentrations can be 284 produced by hybridization of sediment-derived melt with the mantle-wedge due to variable $\mathrm{H}_{2} \mathrm{O}$ 285 concentration and pressure of hybridization, with higher pressure hydrous melts being more silica286 undersaturated than lower pressure melt compositions.

287 Certain differences in melt compositions are also observed as a function of increasing bulk $\mathrm{H}_{2} \mathrm{O}$ 288 in the partial melting of sediment-melt fluxed peridotite (Figure 5). $\mathrm{SiO}_{2}$ concentrations of partial melts 289 with 4 and 6 wt.\% bulk $\mathrm{H}_{2} \mathrm{O}$ are lower than those with 2 wt.\% bulk water at $3 \mathrm{GPa}$, around similar 290 degrees of partial melting. At higher bulk $\mathrm{H}_{2} \mathrm{O}$ contents, garnet, clinopyroxene and phlogopite are 291 consumed at lower degrees of partial melting. Thus, $\mathrm{Al}_{2} \mathrm{O}_{3}, \mathrm{CaO}$, and $\mathrm{K}_{2} \mathrm{O}$ display mostly incompatible 292 behavior, i.e.,decreasing concentration with increasing degree of partial melting. This is unlike the 293 partial melt compositions with 2 wt.\% bulk $\mathrm{H}_{2} \mathrm{O}$ where compatible behavior is observed for these oxides 294 at lower degrees of partial melting due to the presence of garnet, clinopyroxene and phlogopite. It may 295 appear that partial melt compositions produced in experiments with higher bulk $\mathrm{H}_{2} \mathrm{O}$ are more enriched 296 in $\mathrm{FeO}^{*}$ (especially at $3 \mathrm{GPa}$ ), whereas, it is possible that the higher $\mathrm{FeO}^{*}$ concentration is the result of 297 lower Fe-loss in the experiments in this study as compared to those from Mallik et al. (2015). MgO 
content increases with increasing temperature and bulk $\mathrm{H}_{2} \mathrm{O}$ concentration (Figure 6). This is related to 299 the degree of partial melting $(F)$, i.e., at constant bulk $\mathrm{H}_{2} \mathrm{O}$ content, $F$ increases with temperature, and at constant temperature, $F$ increases with higher bulk $\mathrm{H}_{2} \mathrm{O}$ contents. Higher $F$ increases $\mathrm{MgO}$ content of 301 the melt (Figure 5), $\mathrm{MgO}$ being a compatible component.

Isobaric melt productivity (which determines how fluxing agents control the process of melting 303 in subduction zones) in peridotites is reduced by the presence of $\mathrm{H}_{2} \mathrm{O}$, because $\mathrm{H}_{2} \mathrm{O}$ initiates melting at 304 lower temperatures and minerals have reduced participation in melting processes at lower temperatures. 305 Approximating isobaric melt productivity as a linear function at melt fractions $\geq 10 \mathrm{wt} . \%$, Mallik et al. 306 (2015) found that at 2 and $3 \mathrm{GPa}, 2 \mathrm{wt} . \% \mathrm{H}_{2} \mathrm{O}$ - bearing sediment-melt+peridotite lithology has a similar 307 melt productivity $\left(0.14-0.15 \mathrm{wt} . \% /{ }^{\circ} \mathrm{C}\right.$ at melt fraction of 7 to $\left.35 \mathrm{wt} . \%\right)$ as peridotite $+\mathrm{H}_{2} \mathrm{O}$ at $3.5 \mathrm{GPa}$ $308\left(0.10-0.13 \mathrm{wt} . \% /{ }^{\circ} \mathrm{C}\right.$ at melt fraction of 18 to $\left.31 \mathrm{wt} . \%\right)$. This indicates that the nature of fluxing agent 309 (hydrous sediment-melt versus aqueous fluid) has minor effect on the melt productivity of the 310 assemblage. Combining results from this study with the study by Mallik et al. (2015), it is observed that 3114 wt.\% $\mathrm{H}_{2} \mathrm{O}$-bearing sediment-melt+peridotite assemblage has an isobaric melt productivity of $0.2 \mathrm{wt} . \% /$ $312{ }^{\circ} \mathrm{C}$ at $3 \mathrm{GPa}$ (melt fractions from 24 to $35 \mathrm{wt} . \%$ ) and 6 wt. $\% \mathrm{H}_{2} \mathrm{O}$-bearing sediment-melt+peridotite 313 lithology has an isobaric melt productivity of $0.18 \mathrm{wt} . \% /{ }^{\circ} \mathrm{C}$ at $3 \mathrm{GPa}$ (melt fractions from 21 to 46 314 wt.\%) (Figure 3). This corroborates the fact that at $3 \mathrm{GPa}$, irrespective of $\mathrm{H}_{2} \mathrm{O}$ content, peridotite 315 hybridized by hydrous sediment-melt has a melt productivity that is similar to peridotite fluxed by $\mathrm{H}_{2} \mathrm{O}$ 316 only. At $2 \mathrm{GPa}$, however, 4 and $6 \mathrm{wt} . \%$ sediment-melt+peridotite mixtures have isobaric melt 317 productivities of $0.24 \mathrm{wt.} \% /{ }^{\circ} \mathrm{C}$ (at melt fractions of 24 to $53 \mathrm{wt} . \%$ ) and $0.32 \mathrm{wt} . \% /{ }^{\circ} \mathrm{C}$ (at melt fractions 318 of 45 to $61 \mathrm{wt} . \%$ ), which are higher than the melt productivities of the same lithology at $3 \mathrm{GPa}$, 319 irrespective of bulk $\mathrm{H}_{2} \mathrm{O}$ content. Thus, it appears that lower pressure of melting increases melt 320 productivity for the same amount of bulk $\mathrm{H}_{2} \mathrm{O}$ present, especially at higher bulk $\mathrm{H}_{2} \mathrm{O}$ contents. 
Mallik et al. (2015) demonstrated that the difference in composition of partial melts of peridotite

322 fluxed by hydrous sediment-melt versus only $\mathrm{H}_{2} \mathrm{O}$ is due to a difference in bulk composition of the two

323 lithologies, such as, higher $\mathrm{SiO}_{2}, \mathrm{Al}_{2} \mathrm{O}_{3}, \mathrm{Na}_{2} \mathrm{O}$ and $\mathrm{K}_{2} \mathrm{O}$ and lower $\mathrm{FeO}$ *, $\mathrm{MgO}$ and $\mathrm{CaO}$. A similar

324 observation is made when partial melt compositions of 4 and 6 wt. $\% \mathrm{H}_{2} \mathrm{O}$-bearing sediment-

325 melt + peridotite mixtures are compared with partial melt compositions of hydrous peridotite at similar

326 pressure conditions as this study (Figure 4). This reinforces the argument that bulk compositional

327 control or the nature of fluxing agent has a strong effect on partial melt compositions of peridotite, even

328 though isobaric melt productivity remains similar.

\subsection{Effect of water and pressure on silica activity of mantle-derived partial melts}

Several studies have investigated the effect of $\mathrm{H}_{2} \mathrm{O}$ on partial melting of mantle lithologies, and it

332 has been observed that hydrous partial melts of spinel peridotite (pressure of magma generation $<2.5$

$333 \mathrm{GPa}$ ) are more siliceous than hydrous partial melts of garnet peridotite (pressure of magma generation $\geq$

334 2.5 GPa) (e.g. Hirose, 1997; Hirose and Kawamoto, 1995; Irving and Green, 2008; Tenner et al., 2012).

335 Also, whereas a trend is not conspicuous for melts generated at $2 \mathrm{GPa}$ and shallower, for deeper hydrous 336 mantle melts, the $\mathrm{SiO}_{2}$ concentration of the melt decreases with increasing melt $\mathrm{H}_{2} \mathrm{O}$ concentration, the 337 exception being that vapor-saturated mantle melts are very siliceous (Figure 7). In order to explain how $338 \mathrm{H}_{2} \mathrm{O}$ affects partial melting and the difference in the effect of $\mathrm{H}_{2} \mathrm{O}$ at the two pressure ranges, we 339 estimated the activity coefficient of silica $\left(\Upsilon_{\mathrm{SiO} 2}\right)$ of mantle-derived partial melts (both anhydrous and 340 hydrous) saturated with olivine and orthopyroxene, as a function of melt $\mathrm{H}_{2} \mathrm{O}$ content for spinel and 341 garnet-bearing mantle lithologies.

342 In a mantle-derived melt saturated with olivine and orthopyroxene at the liquidus, the activity of 343 silica $\left(a_{\mathrm{SiO} 2}\right)$ is buffered by the following reaction: 
$\mathrm{Mg}_{2} \mathrm{SiO}_{4}+\mathrm{SiO}_{2} \rightarrow \mathrm{Mg}_{2} \mathrm{Si}_{2} \mathrm{O}_{6}$

345 (Olivine) (Melt) (Orthopyroxene)

346 From equation 1, the following relation can be derived from equilibrium thermodynamics:

$347 \operatorname{lnaSiO2}=\Delta G O R T+1 R T 1 P \Delta V d P+\operatorname{lnaEnOpxaFoOl}$

348 where, $a \mathrm{SiO} 2=$ activity of $\mathrm{SiO}_{2}$ in the melt

explained in Supplementary Information.

$\Delta G O=$ Gibbs free energy of the end-members in the reaction at $T$ of reaction and $P$ of 1 bar

$\Delta V \quad=$ Molar volume change of the reaction at $T$ of the reaction and $P$ of 1 bar

$a E n O p x \quad=$ Activity of enstatite in orthopyroxene at $P-T$ of the reaction

aFoOl= Activity of forsterite in olivine at $P-T$ of the reaction

$R \quad=$ Molar gas constant

The methods of calculation of $a \mathrm{SiO} 2$ and $\Upsilon_{\mathrm{SiO} 2}$ of the melt compositions using Equation 2 are $\Upsilon_{\mathrm{SiO} 2}$ increases with increasing melt $\mathrm{H}_{2} \mathrm{O}$ concentration, with $\Upsilon_{\mathrm{SiO} 2}$ increasing to 1 for melts generated at $2 \mathrm{GPa}$ and shallower, and $\Upsilon_{\mathrm{SiO} 2}$ increasing to $>1$ for melts generated deeper than $2 \mathrm{GPa}$. $\mathrm{H}_{2} \mathrm{O}$ mixing in silicate liquids is non-ideal and $\mathrm{H}_{2} \mathrm{O}$ interacts with silica components during mixing, which has also been demonstrated by Gaetani and Grove (1998) and Médard and Grove (2008) . At pressures of $2 \mathrm{GPa}$ and shallower, melt compositions having low $\mathrm{H}_{2} \mathrm{O}$ contents with $\Upsilon_{\mathrm{SiO}_{2}}<1$ likely have

363 higher pressures $(>2 \mathrm{GPa}), \Upsilon_{\mathrm{SiO} 2}$ exceeding 1 implies a positive deviation from ideal solution, implying $\mathrm{H}_{2} \mathrm{O}$ mostly dissolved as $\mathrm{OH}^{-}$in the silicate melt structure. As $\Upsilon_{\mathrm{SiO} 2}$ approaches $1, \mathrm{H}_{2} \mathrm{O}$ in the silicate melt likely dissolves as molecular $\mathrm{H}_{2} \mathrm{O}$, placed in the ionic porosity of the silicate melt structure. At 
364 that excess energy is required to place the molecular $\mathrm{H}_{2} \mathrm{O}$ in the ionic porosity of the silicate structure, 365 probably due to a combination of saturation of ionic porosity and due to reduction of ionic porosity due 366 to compressibility of the silicate melt at higher pressures. Also, a recent study investigating mechanism 367 of $\mathrm{H}_{2} \mathrm{O}$ incorporation in silicate melt structures using first principles molecular dynamic simulations 368 (Bajgain et al., 2015) has demonstrated the preferred existence of bridging species and polyhedral edge 369 decorations (hydroxyls connected by hydrogen bonding) at high pressures at the expense of hydroxyls 370 (not connected by hydrogen bonding) as well as molecular water. Such high values of $\Upsilon_{\mathrm{SiO2}}$ at values of $371 \mathrm{a}_{\mathrm{SiO} 2}$ buffered by equation 1 indicate approach towards immiscibility or aqueous fluid saturation.

372 Interestingly, with aqueous fluid saturation in the presence of melt, $\Upsilon_{\mathrm{SiO} 2}$ decreases indicating approach 373 towards ideal mixing of $\mathrm{H}_{2} \mathrm{O}$ in the silicate melt. 2 GPa melts have lower $\Upsilon_{\mathrm{SiO} 2}$ than 3 GPa melts for 374 similar $\mathrm{H}_{2} \mathrm{O}$ concentrations, the difference in $\Upsilon_{\mathrm{SiO} 2}$ increasing at higher melt $\mathrm{H}_{2} \mathrm{O}$ concentrations. Melt 375 compositions with higher $\Upsilon_{\mathrm{SiO} 2}$ likely display higher structural connectivity due to the presence of 376 connected $\mathrm{H}_{2} \mathrm{O}$ species. This enhances orthopyroxene to olivine formation, thus melts generated at $>2$ $377 \mathrm{GPa}$ are more silica deficient than melts generated below $2 \mathrm{GPa}$, as long as no aqueous fluid coexists 378 with the melt. Hence, it appears that at higher pressure, the effect of $\mathrm{H}_{2} \mathrm{O}$ on partial melting is similar to 379 that of $\mathrm{CO}_{2}$ i.e. higher orthopyroxene to olivine ratio resulting in lowering of silica concentration of the 380 melt compositions (Dasgupta et al., 2007; Dasgupta et al., 2013). Aqueous fluid co-existing with the 381 melt causes decrease in $\Upsilon_{\mathrm{SiO} 2}$, resulting in suppressed orthopyroxene to olivine formation. This also 382 results in aqueous fluid-present melt compositions being more siliceous than aqueous fluid383 undersaturated melt compositions. This is a potential explanation for aqueous fluid-present near-solidus 384 partial melts of hydrous metasomatised lherzolites produced at 3.2 GPa being granitic (Grove and Till, 385 2014). Future studies employing in-situ techniques (in order to avoid quench modification) that would 
complement first principles studies, are required to verify the differential speciation of dissolved $\mathrm{H}$ in

387 silicate melts as a function of pressure.

4.3 Trace element signature of residual melts formed by metasomatism of the mantle-wedge by sediment-derived melt source. However, it is important to understand if the slab-derived fluids undergo significant change in trace element signatures during their reactive transport through the mantle-wedge (Pirard and Hermann, 2015).

The starting materials used in this study have not been doped with trace elements; hence, trace element concentrations in the partial melts could not be measured. Instead, the trace element concentrations of

\subsubsection{Trace element patterns of partial melt compositions derived by hybridization of hot mantle-}

$400 \quad$ wedge by sediment-melt

Trace element signatures of infiltrating sediment-melt and natural arc lavas, such as high over to the primary arc lava, without modification by the process of metasomatism. The overall trace element pattern of infiltrating sediment-melt is preserved after metasomatism and subsequent melting of 406 the metasomatised lithology irrespective of the mode of sediment-melt flow through the mantle-wedge, 407 i.e. for porous transport at the hotter core of the mantle-wedge (this study, Mallik et al., 2015) and 408 channelized transport from slab-top to hotter core of the mantle-wedge (Pirard and Hermann, 2015). 
409 This is because the dominant mineralogy of the residue of metasomatism of peridotite by hydrous

410 sediment-melt consists of olivine and orthopyroxene, both minerals that do not fractionate trace

411 elements from one another. There is approximately $14 \mathrm{wt} . \%$ or less phlogopite present in the

412 experiments from Mallik et al. (2015) and this study; however, it appears that the modal proportions of

413 phlogopite (that could potentially deplete the coexisting melt in LILEs such as $\mathrm{Cs}, \mathrm{Rb}$ and $\mathrm{Ba}$ ) are not

414 high enough to alter the overall trace element pattern of the residual melts post metasomatism.

415 The fact that our experiments simulate natural subduction zone processes is further corroborated

416 by the modeled trace element signatures of the orthopyroxenes and the bulk residue of partial melting of

417 the hybridized mantle-wedge from our studies matching those of orthopyroxenes and

418 peridotites/pyroxenites from supra-subduction zones (representing crust-mantle interaction) in terms of

419 positive $\mathrm{U}$ and $\mathrm{Pb}$ anomalies and negative $\mathrm{Nb}$ anomaly (Supplementary Figure 5).

\subsubsection{Effect of hybridization of mantle-wedge on $\mathrm{K}_{2} \mathrm{O} / \mathrm{H}_{2} \mathrm{O}$ and $\mathrm{H}_{2} \mathrm{O} / \mathrm{Ce}$ ratio of the sediment-melt}

estimate the slab-top temperatures in arcs. According to Hermann and Spandler $(2008), \mathrm{K}_{2} \mathrm{O} / \mathrm{H}_{2} \mathrm{O}$ ratios

425 in sediment-derived fluids/melts depend on whether the slab-derived input to the arc source is a fluid or

426 melt. A fluid would result in very low $\mathrm{K}_{2} \mathrm{O} / \mathrm{H}_{2} \mathrm{O}$ ratio $(<<0.002)$. Melting of phengite (in sediments) in 427 fluid-present conditions will result in $\mathrm{K}_{2} \mathrm{O} / \mathrm{H}_{2} \mathrm{O}$ varying from $0.1-1$, and fluid-absent melting of phengite 428 will result in $\mathrm{K}_{2} \mathrm{O} / \mathrm{H}_{2} \mathrm{O}$ ratios of $\sim 2$, (given by the stoichiometry of $\mathrm{K}_{2} \mathrm{O}$ and $\mathrm{H}_{2} \mathrm{O}$ in phengite). Fluid429 absent sediment melting resulting in exhaustion of phengite will cause the $\mathrm{K}_{2} \mathrm{O} / \mathrm{H}_{2} \mathrm{O}$ ratio of the slab430 derived component to be between 1 and 2. The $\mathrm{H}_{2} \mathrm{O} / \mathrm{Ce}$ ratio of sediment-melts, on the other hand, is 431 determined by the presence of allanite and monazite during sediment melting. 
Pirard and Hermann (2015) investigated porous and channelized flow of sediment-melt through 433 the mantle-wedge at the slab-mantle interface. They reported that the $\mathrm{K}_{2} \mathrm{O} / \mathrm{H}_{2} \mathrm{O}$ ratio of the residual 434 melt, during metasomatism of peridotite by porous flow of sediment-melt, is reduced by the formation 435 of phlogopite to the extent that the $\mathrm{K}_{2} \mathrm{O} / \mathrm{H}_{2} \mathrm{O}$ ratio of the residual melts may exit the field of natural arc 436 lavas (Figure 8). Channelized flow of sediment-melt through the mantle-wedge at the slab-mantle 437 interface preserves the $\mathrm{K}_{2} \mathrm{O} / \mathrm{H}_{2} \mathrm{O}$ and $\mathrm{H}_{2} \mathrm{O} / \mathrm{Ce}$ ratios of the residual melts because such a mode of 438 metasomatism leaves olivine and orthopyroxene in the residue, and neither of these minerals incorporate $439 \mathrm{H}_{2} \mathrm{O}, \mathrm{K}$ and $\mathrm{Ce}$ in their structure; hence, does not alter such ratios in melts. On the basis of such an 440 argument, Pirard and Hermann (2015) concluded that arc lavas with sediment signatures are formed by 441 channelized flow of sediment-melt at the slab-mantle interface rather than porous flow. In this study, we 442 investigate the hybridization of the mantle-wedge at $P$ - $T$ conditions existing in its hotter core (Syracuse 443 et al., 2010)-by sediment-melt and subsequent partial melting of the hybridized lithology. We find: partial melts of the hybridized lithology (Figure 8, Table 3), i.e., the ratios in the infiltrating sediment446 melt are preserved in the subsequent partial melts. The only exception appears to be the partial melt 447 composition (estimated by electron microprobe) generated at $3 \mathrm{GPa}$ with 4 wt. $\%$ bulk $\mathrm{H}_{2} \mathrm{O}$, where the $448 \mathrm{~K}_{2} \mathrm{O} / \mathrm{H}_{2} \mathrm{O}$ ratio of this melt composition $(0.07 \pm 0.01)$ is much lower than the $\mathrm{K}_{2} \mathrm{O} / \mathrm{H}_{2} \mathrm{O}$ of its infiltrating 449 sediment-melt with $16 \mathrm{wt} . \% \mathrm{H}_{2} \mathrm{O}(0.34)$. This difference may be attributed to the lower estimation of $450 \quad \mathrm{~K}_{2} \mathrm{O}$ concentrations in melt by electron microprobe due to loss of K-bearing quench phases from the 451 surface during polishing. When the melt composition was estimated by LA-ICPMS for the same 452 experiment, the difference between $\mathrm{K}_{2} \mathrm{O} / \mathrm{H}_{2} \mathrm{O}$ ratios of the partial melt $(0.21 \pm 0.05)$ and the infiltrating 453 sediment-melt (0.34) are greatly reduced. The reason why $\mathrm{K}_{2} \mathrm{O} / \mathrm{H}_{2} \mathrm{O}$ and $\mathrm{H}_{2} \mathrm{O} / \mathrm{Ce}$ ratios of infiltrating 454 sediment-melts and reacted partial melts do not differ significantly is because the primary residual 
455 minerals formed in the experiments from this study and Mallik et al. (2015) are olivine and

456 orthopyroxene, neither of which incorporates $\mathrm{K}, \mathrm{H}_{2} \mathrm{O}$ or $\mathrm{Ce}$ in their structure. Some experiments do 457 contain minor to trace amount of phlogopite, which would affect the $\mathrm{K}_{2} \mathrm{O} / \mathrm{H}_{2} \mathrm{O}$ ratio, if only slightly so.

458 If one were to calculate slab-top temperatures using the $\mathrm{K}_{2} \mathrm{O} / \mathrm{H}_{2} \mathrm{O}$ and $\mathrm{H}_{2} \mathrm{O} / \mathrm{Ce}$ ratios of infiltrating 459 sediment-melts and reacted partial melts using the thermometers of Plank et al. (2009) and Cooper et al. 460 (2012), it is observed that the temperatures determined using ratios of sediment-melts and reacted melts 461 converge well, within error (Table 3). This demonstrates that slab-derived components could retain the 462 memory of geochemical fingerprints and this may be utilized for slab-top temperature estimates, 463 provided the following conditions are met: (1) only minor to trace amount of hydrous phases are formed 464 during reactive crystallization of the slab-component through the mantle-wedge, (2) no accessory phases 465 crystallize during the process of metasomatism. The geodynamic scenarios (i) and (ii) proposed to be 466 applicable for the experiments in this study (see the following section) support the former condition. 467 Accessory phases being present in mantle-wedge peridotitic samples is very rare (Tumiati et al., 2005), 468 and no accessory phases crystallized in the hybridization experiments of Pirard and Hermann (2015), 469 which were doped with trace elements. This indicates that the latter condition, i.e., no accessory phases 470 crystallize during metasomatism, is likely fulfilled.

471 b) $T$ he $\mathrm{K}_{2} \mathrm{O} / \mathrm{H}_{2} \mathrm{O}$ and $\mathrm{H}_{2} \mathrm{O} / \mathrm{Ce}$ ratios of the partial melts from this study and Mallik et al. (2015) 472 lie mostly within the field of natural arc lavas (Cooper et al., 2012) (Figure 8), although towards the high $473 \mathrm{~K}_{2} \mathrm{O} / \mathrm{H}_{2} \mathrm{O}$ ratio extremity, which could simply be because the sediment-melts used in our study were 474 relatively $\mathrm{H}_{2} \mathrm{O}$-poor compared to those generated by fluid-present melting of subducting sediments. 475 Also, diapiric rise of sediments from the slab-top and subsequent melting of these sediments in the 476 hotter core of the mantle-wedge also appear to produce sediment-melt compositions that would lie 
477 outside the field of natural arc lavas in terms of $\mathrm{K}_{2} \mathrm{O} / \mathrm{H}_{2} \mathrm{O}$ and $\mathrm{H}_{2} \mathrm{O} / \mathrm{Ce}$ ratios (Pirard and Hermann, 478 2015).

$480 \quad 4.4$ Geodynamic scenarios applicable for this study with respect to hybridization of mantle-wedge by 481 sediment-melt

482 The following geodynamic scenarios are proposed in order to showcase how the experiments in 483 this study and those in Mallik et al. (2015) are applicable to natural subduction zone processes (Figure 484 9):

485 i) The residual melts due to focused flow of sediment-melt through the mantle-wedge at the 486 slab-mantle interface from Pirard and Hermann (2015) are rhyolitic on a volatile-free basis and very close in composition to the infiltrating sediment-melt used in this study and Mallik et al., (2015). Therefore, the focused flow residual melts from Pirard and Hermann (2015), after their formation at the slab-mantle-wedge interface can continue to the core of the mantle-wedge where they can hybridize it. Subsequent partial melting of the hybridized lithology can take place, as simulated in this study and Mallik et al. (2015).

ii) Sediment-melt generated at the slab-top can completely freeze in the mantle-wedge at the slab-mantle interface, i.e., if $\mathrm{H}_{2} \mathrm{O}$ in the sediment-melt can be incorporated completely by hydrous minerals, which may be possible if slab melting occurs at fluid-absent or fluid-poor conditions in relatively hot subduction zones (Tsuno and Dasgupta, 2012; Tsuno et al., 2012). The hybridized lithology can rise to the core of the mantle-wedge as part of a mélange diapir, where it can undergo subsequent partial melting.

iii) Porous flow of sediment-melt through the mantle-wedge at the slab-mantle interface creates a phlogopite-rich high $\mathrm{K}_{2} \mathrm{O} / \mathrm{H}_{2} \mathrm{O}$ residue and a coexisting residual low $\mathrm{K}_{2} \mathrm{O} / \mathrm{H}_{2} \mathrm{O}$ melt (step 1). 
The residual low $\mathrm{K}_{2} \mathrm{O} / \mathrm{H}_{2} \mathrm{O}$ melt rises through the mantle-wedge via channelized mode of transfer, and interacts with a preexisting phlogopite-rich, high $\mathrm{K}_{2} \mathrm{O} / \mathrm{H}_{2} \mathrm{O}$ residue from a previous episode of metasomatism in the hotter core of the mantle-wedge (step 2). If the melt-rock ratio during step 1 is the same as that during step 2, the $\mathrm{K}_{2} \mathrm{O} / \mathrm{H}_{2} \mathrm{O}$ ratio of the original sediment-melt will be reproduced in the final primary arc lava produced by the twostep hybridization. However, the melt-rock ratios being the same at the two steps would be fortuitous. Hence, this scenario, although applicable for the experiments performed in this study, is not favorable for preservation of $\mathrm{K}_{2} \mathrm{O} / \mathrm{H}_{2} \mathrm{O}$ ratio of the original sediment-melt in the primary arc lava. In fact, if this fractionation and two-step process sets the $\mathrm{K}_{2} \mathrm{O} / \mathrm{H}_{2} \mathrm{O}$ ratio of primary arc magmas, such ratio may not have any bearing on the slab surface temperatures. However, the $\mathrm{H}_{2} \mathrm{O} / \mathrm{Ce}$ ratio of the sediment-melt will be preserved through the two-step hybridization process and transferred to the primary arc lava. This is due to the fact that no phases involved in the hybridization processes fractionate $\mathrm{H}_{2} \mathrm{O}$ from Ce. Subsequent partial melting of this hybridized lithology will create partial melt compositions akin to those produced in this study and Mallik et al. (2015).

All of the above geodynamic scenarios require that the infiltrating sediment-melt compositions with variable $\mathrm{H}_{2} \mathrm{O}$ concentrations, used in this study and Mallik et al. (2015), are produced at slab-top conditions in subduction zones. According to Table 3, the slab-top temperature produced by the lowest $\mathrm{H}_{2} \mathrm{O}$-bearing sediment-melt $\left(8\right.$ wt. $\left.\% \mathrm{H}_{2} \mathrm{O}, 850-960{ }^{\circ} \mathrm{C}\right)$ may be produced at the slab-top at $3 \mathrm{GPa}$ only in the hottest subduction zones such as Cascadia and Mexico (Syracuse et al., 2010). However, the geodynamic scenarios described above are valid even for hydrous silica-rich partial melts that are generated by lower degree partial melting 
of wet sediments, formed at lower slab-top temperatures found in subduction zones colder than Cascadia and Mexico.

\section{5. Conclusions}

Partial melting of a hydrous sediment-fluxed peridotite at variable pressure, temperature and

527 bulk water contents produces hydrous melt with olivine + orthopyroxene \pm garnet \pm phlogopite in the 528 residue. A variety of primary arc lavas (from foidites to basaltic andesites) can be formed by 529 hybridization of sediment-derived melt with the mantle-wedge, with the more silica-undersaturated, and $530 \mathrm{MgO}$-rich melts being formed at higher concentrations of $\mathrm{H}_{2} \mathrm{O}$ in the melt and higher pressure. Fluxing 531 peridotite with hydrous sediment-melt versus $\mathrm{H}_{2} \mathrm{O}$ does not affect the isobaric melt productivity at 532 higher pressures, although the melt productivity increases with increasing bulk $\mathrm{H}_{2} \mathrm{O}$ concentration at 533 lower pressures. Also, the differential effect of $\mathrm{H}_{2} \mathrm{O}$ with pressure on silica composition of the partial 534 melts of mantle lithologies can be explained by changing $\Upsilon_{\mathrm{SiO} 2}$ of the melt with pressure, which, in turn, 535 is a function of $\mathrm{H}$ speciation in the melt. This study also demonstrates that the process of hydrous 536 metasomatism of mantle-wedge by slab-derived sediment-melts does not affect trace element 537 characteristics of the slab/sediment-melt as long as minor to trace hydrous minerals and no accessory 538 minerals remain in the residue during the course of hybridization; hence, primary arc lavas formed by 539 such a process will retain the geochemical signature of the slab input. This is particularly the case if 540 mantle-wedge hybridization occurs with relatively $\mathrm{H}_{2} \mathrm{O}$-rich sediment partial melt, which would 541 destabilize phlogopite at much lower temperatures thereby preserving the $\mathrm{K}_{2} \mathrm{O} / \mathrm{H}_{2} \mathrm{O}$ ratio of the original 542 slab melt. 
A.M. acknowledges Cin-Ty Lee and Hehe Jiang for assistance with using the LA-ICPMS at Rice

University as well as data reduction, Bob Myhill for providing a spreadsheet to calculate Gibbs free

energy using Holland and Powell (2011), Megan Duncan for sharing her figure of subduction zone,

548 which was modified in Figure 9a, Suraj Bajgain, Mainak Mookerjee, Hans Keppler, Róbert Arató and

549 Pierre Condamine for useful discussions. Cassian Pirard, Alicia Cruz-Uribe and an anonymous reviewer

550 are thanked for constructive reviews that helped improve the manuscript. Horst Marschall is thanked for

551 his constructive reviews as Associate Editor. This work received support from a) the US National

552 Science Foundation grant EAR-1255391 to R.D., b) the Visiting Scientist Program at Bayerisches

553 Geoinstitut and Alexander von Humboldt Postdoctoral fellowship to A.M during the manuscript

554 preparation stage.

555

556

557

558

559

560

561

562

563

564

565

566

567

568

569

570

571

572

573

574

\section{References:}

Auzanneau, E., Vielzeuf, D. and Schmidt, M.W. (2006) Experimental evidence of decompression melting during exhumation of subducted continental crust. Contributions to Mineralogy and Petrology $152,125-148$.

Bajgain, S., Ghosh, D.B. and Karki, B.B. (2015) Structure and density of basaltic melts at mantle conditions from first-principles simulations. Nat Commun 6, doi: 10.1038/ncomms9578.

Barr, J. and Grove, T. (2010) AuPdFe ternary solution model and applications to understanding the fO2 of hydrous, high-pressure experiments. Contributions to Mineralogy and Petrology 160, 631-643.

Bas, M.J.L., Maitre, R.W.L., Streckeisen, A., Zanettin, B. and Rocks, I.S.o.t.S.o.I. (1986) A Chemical Classification of Volcanic Rocks Based on the Total Alkali-Silica Diagram. Journal of Petrology 27, 745-750.

Cooper, L.B., Ruscitto, D.M., Plank, T., Wallace, P.J., Syracuse, E.M. and Manning, C.E. (2012) Global variations in $\mathrm{H} 2 \mathrm{O} / \mathrm{Ce}$ : 1. Slab surface temperatures beneath volcanic arcs. Geochemistry, Geophysics, Geosystems 13, Q03024, doi: 10.1029/2011GC003902.

Dasgupta, R., Hirschmann, M.M. and Smith, N.D. (2007) Partial Melting Experiments of Peridotite + $\mathrm{CO}_{2}$ at $3 \mathrm{GPa}$ and Genesis of Alkalic Ocean Island Basalts. Journal of Petrology 48, 2093-2124.

Dasgupta, R., Mallik, A., Tsuno, K., Withers, A.C., Hirth, G. and Hirschmann, M.M. (2013) Carbondioxide-rich silicate melt in the Earth's upper mantle. Nature 493, 211-215. 
Davis, F.A., Tangeman, J.A., Tenner, T.J. and Hirschmann, M.M. (2009) The composition of KLB-1 peridotite. American Mineralogist 94, 176-180.

England, P.C. and Katz, R.F. (2010) Melting above the anhydrous solidus controls the location of volcanic arcs. Nature 467, 700-703.

Falloon, T.J. and Green, D.H. (1988) Anhydrous partial melting of peridotite from 8 to $35 \mathrm{~kb}$ and the petrogenesis of MORB. J. petrol 29, 379-414.

Falloon, T.J., Green, D.H., Hatton, C.J. and Harris, K.L. (1988) Anhydrous partial melting of a fertile and depleted peridotite from 2 to $30 \mathrm{~kb}$ and application to basalt petrogenesis. Journal of Petrology 29, 1257-1282.

Foley, S.F. (2011) A Reappraisal of Redox Melting in the Earth's Mantle as a Function of Tectonic Setting and Time. Journal of Petrology 52, 1363-1391.

Gaetani, G.A. and Grove, T.L. (1998) The influence of water on melting of mantle peridotite.

Contributions to Mineralogy and Petrology 131, 323-346.

Gonzalez, J., Mao, X.L., Roy, J., Mao, S.S. and Russo, R.E. (2002) Comparison of 193, 213 and 266 nm laser ablation ICP-MS. Journal of Analytical Atomic Spectrometry 17, 1108-1113.

Grassi, D. and Schmidt, M. (2011) Melting of carbonated pelites at 8-13 GPa: generating K-rich carbonatites for mantle metasomatism. Contributions to Mineralogy and Petrology 162, 169-191.

Grove, T. and Till, C. (2014) Melting Processes at the Base of the Mantle Wedge: Melt Compositions and Melting Reactions for the First Melts of Vapor-Saturated Lherzolite, AGU Fall Meeting Abstracts, p. 4257.

Grove, T.L., Chatterjee, N., Parman, S.W. and Médard, E. (2006) The influence of $\mathrm{H}_{2} \mathrm{O}$ on mantle wedge melting. Earth and Planetary Science Letters 249, 74-89.

Hermann, J. and Green, D.H. (2001) Experimental constraints on high pressure melting in subducted crust. Earth and Planetary Science Letters 188, 149-168.

Hermann, J. and Rubatto, D. (2009) Accessory phase control on the trace element signature of sediment melts in subduction zones. Chemical Geology 265, 512-526.

Hermann, J. and Spandler, C.J. (2008) Sediment Melts at Sub-arc Depths: an Experimental Study. Journal of Petrology 49, 717-740.

Hirose, K. (1997) Melting experiments on lherzolite KLB-1 under hydrous conditions and generation of high-magnesian andesitic melts. Geology 25, 42-44.

Hirose, K. and Kawamoto, T. (1995) Hydrous partial melting of lherzolite at $1 \mathrm{GPa}$ : The effect of H2O on the genesis of basaltic magmas. Earth and Planetary Science Letters 133, 463-473. 
607

608

609

610

611

612

613

614

615

616

617

618

619

620

621

622

623

624

625

626

627

628

629

630

631

632

633

634

635

636

637

638

639

640

Hirose, K. and Kushiro, I. (1993) Partial melting of dry peridotites at high pressures: Determination of compositions of melts segregated from peridotite using aggregates of diamond. Earth and Planetary Science Letters 114, 477-489.

Irving, A.J. and Green, D.H. (2008) Phase Relationships of Hydrous Alkalic Magmas at High Pressures: Production of Nepheline Hawaiitic to Mugearitic Liquids by Amphibole-Dominated Fractional Crystallization Within the Lithospheric Mantle. Journal of Petrology 49, 741-756.

Johnson, M.C. and Plank, T. (2000) Dehydration and melting experiments constrain the fate of subducted sediments. Geochemistry, Geophysics, Geosystems 1, 1007, doi: 10.1029/1999GC000014.

Kägi, R., Müntener, O., Ulmer, P. and Ottolini, L. (2005) Piston-cylinder experiments on H2O undersaturated Fe-bearing systems: An experimental setup approaching fO2 conditions of natural calcalkaline magmas. American Mineralogist 90, 708-717.

Kinzler, R.J. and Grove, T.L. (1992) Primary magmas of mid-ocean ridge basalts 1. Experiments and methods. Journal of Geophysical Research: Solid Earth 97, 6885-6906, doi: 10.1029/91JB02840.

Kogiso, T., Hirose, K. and Takahashi, E. (1998) Melting experiments on homogeneous mixtures of peridotite and basalt: application to the genesis of ocean island basalts. Earth and Planetary Science Letters 162, 45-61.

Kushiro, I. (1972) Effect of Water on the Composition of Magmas Formed at High Pressures. Journal of Petrology 13, 311-334.

Mallik, A., Nelson, J. and Dasgupta, R. (2015) Partial melting of fertile peridotite fluxed by hydrous rhyolitic melt at 2-3 GPa: implications for mantle wedge hybridization by sediment melt and generation of ultrapotassic magmas in convergent margins. Contributions to Mineralogy and Petrology 169, 1-24.

Mann, U. and Schmidt, M.W. (2015) Melting of pelitic sediments at subarc depths: 1. Flux vs. fluidabsent melting and a parameterization of melt productivity. Chemical Geology 404, 150-167.

McDonough, W.F. and Sun, S.S. (1995) The composition of the Earth. Chem. Geol. 120, 223-253.

Médard, E. and Grove, T. (2008) The effect of H2O on the olivine liquidus of basaltic melts: experiments and thermodynamic models. Contributions to Mineralogy and Petrology 155, 417-432.

Mitchell, A. and Grove, T. (2015) Melting the hydrous, subarc mantle: the origin of primitive andesites. Contributions to Mineralogy and Petrology 170, 1-23.

Morris, J. and Tera, F. (1989) 10Be and 9Be in mineral separates and whole rocks from volcanic arcs: Implications for sediment subduction. Geochimica et Cosmochimica Acta 53, 3197-3206.

Nicholls, I.A. and Ringwood, A.E. (1973) Effect of water on olivine stability in tholeiites and the production of silica-saturated magmas in the island-arc environment. The Journal of Geology, 285-300.

Parman, S.W. and Grove, T.L. (2004) Harzburgite melting with and without $\mathrm{H}_{2} \mathrm{O}$ : Experimental data and predictive modeling. Journal of Geophysical Research: Solid Earth 109, B02201. 
641

Pirard, C. and Hermann, J. (2014) Experimentally determined stability of alkali amphibole in metasomatised dunite at sub-arc pressures. Contributions to Mineralogy and Petrology 169, 1-26.

Pirard, C. and Hermann, J. (2015) Focused fluid transfer through the mantle above subduction zones. Geology 43, 915-918.

Plank, T., Cooper, L.B. and Manning, C.E. (2009) Emerging geothermometers for estimating slab surface temperatures. Nature Geosci 2, 611-615.

Plank, T. and Langmuir, C.H. (1998) The chemical composition of subducting sediment and its consequences for the crust and mantle. Chem. Geol. 145, 325.

Schmidt, M.W. (2015) Melting of pelitic sediments at subarc depths: 2. Melt chemistry, viscosities and a parameterization of melt composition. Chemical Geology 404, 168-182.

Schmidt, M.W., Vielzeuf, D. and Auzanneau, E. (2004) Melting and dissolution of subducting crust at high pressures: the key role of white mica. Earth and Planetary Science Letters 228, 65-84.

Stepanov, A.S., Hermann, J., Rubatto, D. and Rapp, R.P. (2012) Experimental study of monazite/melt partitioning with implications for the REE, Th and U geochemistry of crustal rocks. Chemical Geology 300-301, 200-220.

Syracuse, E.M., van Keken, P.E. and Abers, G.A. (2010) The global range of subduction zone thermal models. Physics of the Earth and Planetary Interiors 183, 73-90.

Takahashi, E. (1986) Melting of a Dry Peridotite KLB-1 up to 14 GPa: Implications on the Origin of Peridotitic Upper Mantle. J. Geophys. Res. 91, 9367-9382.

Tenner, T.J., Hirschmann, M.M. and Humayun, M. (2012) The effect of $\mathrm{H}_{2} \mathrm{O}$ on partial melting of garnet peridotite at 3.5 GPa. Geochem. Geophys. Geosyst. 13, Q03016.

Thomsen, T.B. and Schmidt, M.W. (2008) Melting of carbonated pelites at 2.5-5.0 GPa, silicatecarbonatite liquid immiscibility, and potassium-carbon metasomatism of the mantle. Earth and Planetary Science Letters 267, 17-31.

Till, C.B., Grove, T.L. and Withers, A.C. (2012) The beginnings of hydrous mantle wedge melting. Contributions to Mineralogy and Petrology 163, 669-688.

Tsuno, K. and Dasgupta, R. (2011) Melting phase relation of nominally anhydrous, carbonated peliticeclogite at 2.5-3.0 GPa and deep cycling of sedimentary carbon. Contributions to Mineralogy and Petrology 161, 743-763.

Tsuno, K. and Dasgupta, R. (2012) The effect of carbonates on near-solidus melting of pelite at $3 \mathrm{GPa}$ : Relative efficiency of $\mathrm{H}_{2} \mathrm{O}$ and $\mathrm{CO}_{2}$ subduction. Earth and Planetary Science Letters 319-320, 185-196.

Tsuno, K., Dasgupta, R., Danielson, L. and Righter, K. (2012) Flux of carbonate melt from deeply subducted pelitic sediments: Geophysical and geochemical implications for the source of Central American volcanic arc. Geophysical Research Letters 39, L16307, doi: 10.1029/2012GL052606. 
Tumiati, S., Godard, G., Martin, S., Nimis, P., Mair, V. and Boyer, B. (2005) Dissakisite-(La) from the Ulten zone peridotite (Italian Eastern Alps): A new end-member of the epidote group, American Mineralogist, p. 1177.

Ulmer, P. (2001) Partial melting in the mantle wedge - the role of $\mathrm{H} 2 \mathrm{O}$ in the genesis of mantlederived 'arc-related' magmas. Physics of the Earth and Planetary Interiors 127, 215-232.

Walter, M.J. (1998) Melting of garnet peridotite and the origin of komatiite and depleted lithosphere. J. Petrol. 39, 29-60.

\section{Figure captions:}

Figure 1. (a) and (b) Backscattered electron image of experiment B309 (2 GPa, $1250{ }^{\circ} \mathrm{C}, 4$ wt. $\%$ bulk $\mathrm{H}_{2} \mathrm{O}$ ). (a) Image of the whole capsule showing quenched melt pool in the inner and outer capsules along with a solid residue. (b) Magnification of the white box in a). Quenched melt pool in the outer capsule co-existing with coarser grained olivine and finer grained orthopyroxene. The coarse nature of olivine grains and their location next to the melt indicates that these are likely formed from dissolution and reprecipitation of olivine grains in the original peridotitic composition. (c) Backscattered electron image of experiment $\mathrm{G} 376\left(3 \mathrm{GPa}, 1225^{\circ} \mathrm{C}, 4 \mathrm{wt} . \%\right.$ bulk $\left.\mathrm{H}_{2} \mathrm{O}\right)$ showing orthopyroxene, garnet and phlogopite at the bottom of the outer capsule. Abbreviations used are: $O l$ - olivine; $O p x$ - orthopyroxene; $P h l-$ phlogopite.

Figure 2. Stability of phases in the pressure-temperature-bulk $\mathrm{H}_{2} \mathrm{O}$ concentration space explored in this study and Mallik and Dasgupta (2015). The results from experiments with 2 wt. $\% \mathrm{H}_{2} \mathrm{O}$ are from Mallik and Dasgupta (2015). Dark field indicates presence of a phase. Abbreviations used are: $O l$ - olivine; $O p x$ - orthopyroxene; $C p x$ - clinopyroxene; $P h l$ - phlogopite; $G t$ - garnet. Orthopyroxene and quenched melt are present in all the experiments.

Figure 3. Amount of melt in weight fraction (estimated using melt compositions measured by LAICPMS for experiments B307, B309, G376, G377, G379, G380, G378, G374 and G375) versus temperature for this study compared with previous experimental studies of $\mathrm{H}_{2} \mathrm{O}$-bearing (vaporundersaturated) peridotite partial melting at $3.5 \mathrm{GPa}$ (Tenner et al. 2012), $\mathrm{H}_{2} \mathrm{O}$ vapor-saturated peridotite partial melting at $3.2 \mathrm{GPa}$ (Till et al. 2012) and anhydrous peridotite partial melting at $3 \mathrm{GPa}$ (Walter 1998). Regression lines have been fitted through the melt fractions as a function of temperature. The slopes of the lines are isobaric $\mathrm{dF} / \mathrm{dT}$. This figure is modified from Mallik et al., (2015). The equations of the best-fit lines are as follows: $F=0.13 T-160.09\left(1.5 \mathrm{wt} \% \mathrm{H}_{2} \mathrm{O}\right.$ bearing peridotite $), F=0.13 T-$ $140.2\left(2.5 \mathrm{wt} \% \mathrm{H}_{2} \mathrm{O}\right.$-bearing peridotite), $F=0.10 T-103.2\left(5 \mathrm{wt} \% \mathrm{H}_{2} \mathrm{O}\right.$-bearing peridotite $), F=0.15 T-$ 146.77 (14.5 wt $\% \mathrm{H}_{2} \mathrm{O}$-bearing peridotite), $F=0.15 T-162.91\left(2 \mathrm{GPa}, 2 \mathrm{wt} \% \% \mathrm{H}_{2} \mathrm{O}\right), F=0.24 T-265(2$ $\mathrm{GPa}, 4$ wt. $\% \mathrm{H}_{2} \mathrm{O}$, LA-ICPMS, this study), $F=0.32 T-343$ (2 GPa, 6 wt. $\% \mathrm{H}_{2} \mathrm{O}$, LA-ICPMS, this study), $F=0.14 T-161.33\left(3 \mathrm{GPa}, 2\right.$ wt. $\left.\% \mathrm{H}_{2} \mathrm{O}\right), F=0.22 T-245$ (3 GPa, 4 wt.\% $\mathrm{H}_{2} \mathrm{O}$, LA-ICPMS, this study), $F=0.18 T-181$ ( $3 \mathrm{GPa}, 6$ wt. $\% \mathrm{H}_{2} \mathrm{O}$, LA-ICPMS, this study). 
Figure 4. Partial melt compositions from this study and Mallik et al. (2015) reported on a volatile-free basis (experiments B307, B309, G376, G377, G379, G380, G378, G374 and G375 estimated by LAICPMS, the rest by electron microprobe) compared with partial melts of peridotite $+\mathrm{H}_{2} \mathrm{O}$, and sedimentmelt + olivine. Vapor-absent partial melt compositions of peridotite $+\mathrm{H}_{2} \mathrm{O}$ generated at 1.6-2.0 GPa and $3.5 \mathrm{GPa}$ (pressures ranges closest to 2 and $3 \mathrm{GPa}$, i.e., pressures of melting explored in this study) are taken from Tenner et al. (2011), Mitchell and Grove (2015) and Pirard and Hermann (2015). Vaporpresent partial melt compositions of peridotite $+\mathrm{H}_{2} \mathrm{O}$ generated at $1.6 \mathrm{GPa}$ and $3.2 \mathrm{GPa}$ are taken from Till et al. (2012). The porous flow partial melt compositions of sediment-melt + olivine mixture are taken from Pirard and Hermann $(2014,2015)$.

Figure 5. $\mathrm{SiO}_{2}$ versus total alkali $\left(\mathrm{Na}_{2} \mathrm{O}+\mathrm{K}_{2} \mathrm{O}\right)$ concentration of partial melts from this study and Mallik et al. (2015). The classification of volcanic rocks used in the total alkali-silica figure is from Le Bas et al. (1986) . The dashed line for dividing alkalic and tholeiitic lavas is from Irvine and Baragar (1971). All the partial melt compositions, except those from experiments with $2 \mathrm{wt} . \% \mathrm{H}_{2} \mathrm{O}$ formed at $3 \mathrm{GPa}$ are olivine and orthopyroxene saturated, and have been reported on a volatile-free basis. The partial melt compositions have been determined by electron microprobe in ' $a$ ' and LA-ICPMS in ' $b$ '. Natural arc lavas are compiled from GEOROC (Aegean, Aeolian, Cascades, Central American Volcanic Province, Izu-Bonin, Mariana, Sunda and Tonga) and Mallik et al. (2015) for ultrapotassics. They are filtered for compositions with $\mathrm{MgO}>6 \mathrm{wt} . \%$, and olivine is added until the composition is in equilibrium with $\mathrm{Fo}_{89}$, in order to compare the experimental melt compositions with primary arc lavas.

Figure 6. $\mathrm{MgO}$ content on a water-free basis versus temperature of experiments for partial melt compositions from this study (melt compositions from experiments B307, B309, G376, G377, G379, G380, G378, G374 and G375 determined by LA-ICPMS and the rest by electron microprobe) and Mallik et al., (2015). Line 1 indicates $\mathrm{MgO}$ versus temperature relationship from Ulmer (2001) for anhydrous mantle melt compositions. Lines 2, 3 and 4 are hand drawn to guide the readers to note the $\mathrm{MgO}$ versus temperature relationships for 2, 4 and $6 \mathrm{wt} . \%$ bulk $\mathrm{H}_{2} \mathrm{O}$ systems, respectively from this study. Our data clearly show that partial melts with higher $\mathrm{MgO}$ contents are derived from peridotite at a fixed temperature when fluxed with higher water content. Olivine-orthopyroxene saturated hydrous partial melt compositions from literature (Gaetani and Grove, 1998; Grove et al., 2006; Hirose, 1997; Hirose and Kawamoto, 1995; Kinzler and Grove, 1992; Kogiso et al., 1998; Mitchell and Grove, 2015; Parman and Grove, 2004; Pirard and Hermann, 2014; Pirard and Hermann, 2015; Tenner et al., 2012; Till et al., 2012) are also plotted for comparison.

Figure 7. $\mathrm{SiO}_{2}$ versus $\mathrm{H}_{2} \mathrm{O}$ concentration of melt from this study and Mallik et al. (2015) compared with peridotite $+\mathrm{H}_{2} \mathrm{O}$ melt compositions. (a) Melt compositions from this study are determined by electron microprobe. (b) Melt compositions from experiments B307, B309, G376, G377, G379, G380, G378, G374 (this study) are determined by LA-ICPMS. Silica activity coefficient $\left(\Upsilon_{\mathrm{SiO} 2}\right)$ of olivineorthopyroxene saturated melt as a function of $\mathrm{H}_{2} \mathrm{O}$ concentration in melt, where melt compositions from this study and Mallik et al. (2015) were determined by electron microprobe. (c) $\Upsilon_{\mathrm{SiO} 2}$ calculated by the first method (see Supplementary Information for further details). (d) $\Upsilon_{\mathrm{SiO} 2}$ calculated using by the 
second method (see Supplementary Information for further details), i.e., using the thermodynamic database and equation of state of Holland and Powell, (2011). Peridotite $\pm \mathrm{H}_{2} \mathrm{O}$ partial melt compositions generated at $2 \mathrm{GPa}$ and shallower, without coexisting with vapor (Gaetani and Grove, 1998; Hirose, 1997; Hirose and Kawamoto, 1995; Kinzler and Grove, 1992; Kogiso et al., 1998; Mitchell and Grove, 2015; Parman and Grove, 2004), and coexisting with vapor/fluid (Grove et al., 2006; Till et al., 2012) are plotted along with peridotite $\pm \mathrm{H}_{2} \mathrm{O}$ partial melt compositions generated deeper than $2 \mathrm{GPa}$, without coexisting vapor/fluid (Falloon and Green, 1988; Falloon et al., 1988; Hirose and Kushiro, 1993; Parman and Grove, 2004; Takahashi, 1986; Tenner et al., 2012; Walter, 1998), and coexisting with vapor/fluid (Till et al., 2012). The hydrous sediment-melt+olivine partial melt compositions are taken from Pirard and Hermann $(2014,2015)$. $\Upsilon_{\mathrm{SiO} 2}$ of melt compositions generated deeper than $2 \mathrm{GPa}$, without coexisting with vapor display an increasing trend with melt $\mathrm{H}_{2} \mathrm{O}$ contents represented by the black curve. Melt composition generated deeper than $2 \mathrm{GPa}$, coexisting with vapor/fluid has a lower $\Upsilon_{\mathrm{SiO} 2}$ as compared to melt compositions not coexisting with vapor or fluid. The melt compositions from Pirard and Hermann $(2014,2015)$ with $\mathrm{H}_{2} \mathrm{O}$ concentrations greater than 20 wt.\% are most likely vapor/fluid-present, which would explain their low $\Upsilon_{\mathrm{SiO} 2}$ as compared to $\mathrm{H}_{2} \mathrm{O}$-rich melt compositions generated deeper than $2 \mathrm{GPa}$. $\Upsilon_{\mathrm{SiO} 2}$ calculated by both methods display nearly identical trends of $\Upsilon_{\mathrm{SiO} 2}$ as a function of $\mathrm{H}_{2} \mathrm{O}$ content of melt.

Figure 8. $\mathrm{K}_{2} \mathrm{O} / \mathrm{H}_{2} \mathrm{O}$ and $\mathrm{H}_{2} \mathrm{O} / \mathrm{Ce}$ ratios of natural arc lavas (Cooper et al., 2012), obtained from leastdegassed melt inclusions, and sediment-melts formed in diapirs (Hermann and Spandler, 2008; Stepanov et al., 2012) compared with infiltrating sediment-melts and partial melts of peridotite hybridized with sediment-melt (used in this study and Mallik et al., 2015) as well as low-K and high-K infiltrating sediment-melts and their corresponding reacted melts from porous flow and focused flow of sedimentmelts through dunite (Pirard and Hermann, 2015). (a) Partial melt compositions from this study and Mallik et al. (2015) determined using electron microprobe (b) Partial melt compositions from this study (experiments B307, B309, G376, G377, G379, G380, G378, G374 and G375) determined using LAICPMS. This figure is modified from Figure 3 of Pirard and Hermann (2015).

Figure 9. Geodynamic scenarios applicable for experiments performed in this study and Mallik et al. (2015). The yellow blobs represent final residues of melting that have minor to trace phlogopite or are devoid of phlogopite. a) Sediment-melt from the subducted slab undergoes channelized flow through the mantle to hybridize the mantle-wedge at its hotter core. b) Sediment-melt from the subducted slab completely freezes into the mantle at the slab-mantle interface. The hybridized lithology rises to the hotter core of the mantle-wedge via mélange diapirs. c) Step 1 - sediment-melt from the slab hybridizes the mantle at the slab-mantle interface via porous flow and produces a low $\mathrm{K}_{2} \mathrm{O} / \mathrm{H}_{2} \mathrm{O}$ melt and phlogopite-rich high $\mathrm{K}_{2} \mathrm{O} / \mathrm{H}_{2} \mathrm{O}$ residue. Step 2 - the low $\mathrm{K}_{2} \mathrm{O} / \mathrm{H}_{2} \mathrm{O}$ melt undergoes channelized flow through the mantle-wedge and reacts with a pre-existing high $\mathrm{K}_{2} \mathrm{O} / \mathrm{H}_{2} \mathrm{O}$, potentially phlogopite-bearing residue. The hybridized lithology formed in this second stage undergoes partial melting. For details, refer to the text. If scenario (c) is applicable to nature then the resulting $\mathrm{K}_{2} \mathrm{O} / \mathrm{H}_{2} \mathrm{O}$ ratio of the mantle partial melt may not provide any insight on the slab surface temperatures. 
805

806

807

808 
Table 1. Compositions of starting materials and melt compositions in the experiments

\begin{tabular}{|c|c|c|c|c|c|c|c|c|c|c|c|c|c|c|c|c|c|c|}
\hline $\begin{array}{l}\text { Exp. } \\
\text { No. }\end{array}$ & $\begin{array}{l}\text { Bulk } \\
\mathrm{H}_{2} \mathrm{O} \\
\text { (wt.\%) }\end{array}$ & $\begin{array}{c}\mathrm{P} \\
(\mathrm{GPa})\end{array}$ & $\begin{array}{c}\mathrm{T} \\
\left({ }^{\circ} \mathrm{C}\right)\end{array}$ & $\mathrm{n}$ & $\begin{array}{c}\text { Name of } \\
\text { starting } \\
\text { material / } \\
\text { Phase }\end{array}$ & $\mathrm{SiO}_{2}$ & $\mathrm{TiO}_{2}$ & $\mathrm{Al}_{2} \mathrm{O}_{3}$ & $\mathrm{Cr}_{2} \mathrm{O}_{3}$ & $\mathrm{FeO}^{*}$ & $\mathrm{MnO}$ & $\mathrm{MgO}$ & $\mathrm{CaO}$ & $\mathrm{Na}_{2} \mathrm{O}$ & $\mathrm{K}_{2} \mathrm{O}$ & $\mathrm{P}_{2} \mathrm{O}_{5}$ & Sum & $\mathrm{H}_{2} \mathrm{O}$ \\
\hline & \multirow{4}{*}{\multicolumn{3}{|c|}{ Starting materials }} & & SPMH* & 72.69 & 0.43 & 14.93 & 0 & 0.94 & 0.03 & 0.26 & 0.95 & 3.19 & 6.38 & 0.18 & 100 & \\
\hline & & & & & KLB-1ox ${ }^{\dagger}$ & 44.82 & 0.15 & 3.51 & 0.32 & 8.19 & 0.12 & 39.5 & 3.07 & 0.3 & 0.02 & 0 & 100 & \\
\hline & & & & & SPMHKLB4 & 51.81 & 0.22 & 6.37 & 0.24 & 6.38 & 0.1 & 29.7 & 2.54 & 1.02 & 1.61 & 0.05 & 100.05 & 4 \\
\hline & & & & & SPMHKLB6 & 50.44 & 0.21 & 5.81 & 0.26 & 6.73 & 0.12 & 31.56 & 2.64 & 0.89 & 1.31 & 0.04 & 100 & 6 \\
\hline \multirow[t]{2}{*}{ B307 } & 4 & 2 & 1200 & 134 & Melt $^{1}$ & $50.9(8)$ & $0.63(9)$ & $13.5(5)$ & $0.2(1)$ & $5.1(6)$ & $0.13(3)$ & $14.5(7)$ & $8.3(4)$ & $2.6(3)$ & $4.1(4)$ & $0.03(6)$ & 100.0 & $13.2(4)$ \\
\hline & & & & 5 & Melt $^{2}$ & $47(1)$ & $0.79(4)$ & $16.2(7)$ & $0.091(3)$ & $5.2(2)$ & $0.156(5)$ & $12.5(6)$ & $10.0(4)$ & $3.2(1)$ & $4.8(2)$ & $0.164(7)$ & 100.0 & $16.6(1)$ \\
\hline \multirow[t]{2}{*}{ B309 } & 4 & 2 & 1250 & 108 & Melt $^{1}$ & $50.3(9)$ & $0.57(7)$ & $12.4(5)$ & $0.3(2)$ & $7.4(9)$ & $0.15(4)$ & $15(2)$ & $8(2)$ & $2.7(5)$ & $3.8(1)$ & $0.13(4)$ & 100.1 & $10.4(3)$ \\
\hline & & & & 6 & Melt $^{2}$ & $48.9(8)$ & $0.61(2)$ & $13.22(1)$ & $0.108(3)$ & $6.7(2)$ & $0.127(8)$ & $15(1)$ & $7.6(6)$ & $3.0(4)$ & $4.3(6)$ & $0.15(1)$ & 100.0 & $10.9(3)$ \\
\hline G358 & 4 & 2 & 1300 & 69 & Melt $^{1}$ & $51(1)$ & $0.44(6)$ & $11.0(8)$ & $0.28(9)$ & $7.0(6)$ & $0.13(3)$ & 19(1) & $5.9(6)$ & $1.9(4)$ & $2.7(4)$ & $0.09(3)$ & 100.0 & $7.6(4)$ \\
\hline \multirow[t]{2}{*}{ G376 } & 4 & 3 & 1225 & 82 & Melt $^{1}$ & $46(3)$ & $0.6(1)$ & $13(1)$ & $0.14(6)$ & $7.0(8)$ & $0.14(6)$ & $18(2)$ & $11(2)$ & $3(1)$ & $1.1(7)$ & $0.2(1)$ & 100.0 & $16(4)$ \\
\hline & & & & 8 & Melt $^{2}$ & $41(2)$ & $0.69(3)$ & $13.9(6)$ & $0.149(8)$ & $7.9(2)$ & $0.15(1)$ & $21(1)$ & $8.8(8)$ & $2.6(4)$ & $3.4(4)$ & $0.12(1)$ & 100.0 & $17(1)$ \\
\hline \multirow[t]{2}{*}{ G377 } & 4 & 3 & 1275 & 61 & Melt $^{1}$ & $46(2)$ & $0.5(1)$ & $14(2)$ & $0.13(5)$ & $7.1(7)$ & $0.18(7)$ & $20(2)$ & $9(2)$ & $2.2(7)$ & $1.0(5)$ & $0.1(1)$ & 100.0 & $12(2)$ \\
\hline & & & & 5 & Melt $^{2}$ & $42.7(6)$ & $0.60(2)$ & $13.19(8)$ & $0.163(3)$ & $8.1(2)$ & $0.15(2)$ & $22.4(4)$ & $7(1)$ & $2.20(9)$ & $3.2(4)$ & $0.116(8)$ & 100.0 & $11.5(1)$ \\
\hline \multirow[t]{2}{*}{ G379 } & 6 & 2 & 1200 & 102 & Melt $^{1}$ & $52(2)$ & $0.43(5)$ & $13(2)$ & $0.18(4)$ & $6.2(6)$ & $0.12(4)$ & $16(2)$ & $8(1)$ & $1.7(5)$ & $1.5(4)$ & $0.07(4)$ & 100.0 & 13(3) \\
\hline & & & & 6 & Melt $^{2}$ & $50(2)$ & $0.50(3)$ & $12.0(3)$ & $0.191(8)$ & $7.5(4)$ & $0.144(5)$ & $17(1)$ & $7.5(4)$ & $1.81(8)$ & $2.7(6)$ & $0.074(7)$ & 100.0 & $13.4(6)$ \\
\hline \multirow[t]{2}{*}{ G380 } & 6 & 2 & 1250 & 106 & Melt $^{1}$ & $52(2)$ & $0.36(5)$ & $12(2)$ & $0.24(5)$ & $7.0(7)$ & $0.13(4)$ & $20(2)$ & $5.1(7)$ & $1.4(4)$ & $2.2(7)$ & $0.08(4)$ & 100.0 & $10(2)$ \\
\hline & & & & 8 & Melt $^{2}$ & $50(2)$ & $0.40(3)$ & $10(1)$ & $0.27(2)$ & $7.2(4)$ & $0.154(7)$ & $24(1)$ & $5.3(6)$ & $1.3(1)$ & 2.1(1) & $0.078(3)$ & 100.0 & $9.8(5)$ \\
\hline G381 & 6 & 3 & 1150 & 32 & Melt $^{1}$ & $44(4)$ & $0.7(2)$ & $17(5)$ & $0.10(6)$ & $6(1)$ & $0.14(6)$ & $14(3)$ & $10(2)$ & $5(3)$ & $2.2(9)$ & $0.14(7)$ & 100.0 & $26(2)$ \\
\hline \multirow[t]{2}{*}{ G378 } & 6 & 3 & 1200 & 141 & Melt $^{1}$ & $47(3)$ & $0.5(1)$ & $16(4)$ & $0.15(6)$ & $6.4(7)$ & $0.14(5)$ & $17(3)$ & $9(2)$ & $2.3(7)$ & $2.0(9)$ & $0.12(8)$ & 100.1 & $15.8(3)$ \\
\hline & & & & 6 & Melt $^{2}$ & $45(2)$ & $0.66(3)$ & $12(1)$ & $0.17(1)$ & $7.8(5)$ & $0.17(1)$ & $20(1)$ & $8.5(7)$ & $1.7(1)$ & $3.6(4)$ & $0.078(6)$ & 100.0 & 15.8 \\
\hline \multirow[t]{2}{*}{ G374 } & 6 & 3 & 1250 & 134 & Melt $^{1}$ & $49(2)$ & $0.5(1)$ & $12(2)$ & $0.17(7)$ & $7.5(9)$ & $0.16(6)$ & $18(3)$ & $10(2)$ & $1.8(5)$ & $1.1(7)$ & $0.08(8)$ & 100.0 & $15(1)$ \\
\hline & & & & 7 & Melt $^{2}$ & $44(2)$ & $0.59(3)$ & $12.9(2)$ & $0.19(1)$ & $10.2(3)$ & $0.201(1)$ & $19.2(9)$ & $7.5(8)$ & $1.7(5)$ & $3.2(4)$ & $0.061(6)$ & 100.0 & $15.7(2)$ \\
\hline \multirow[t]{2}{*}{ G375 } & 6 & 3 & 1300 & 67 & Melt $^{1}$ & $49(2)$ & $0.5(1)$ & $13(4)$ & $0.17(7)$ & $4.8(6)$ & $0.16(5)$ & $21(3)$ & $8(3)$ & $1.4(6)$ & $3(1)$ & $0.03(5)$ & 100.0 & $13.1(5)$ \\
\hline & & & & 6 & Melt $^{2}$ & $46.3(8)$ & $0.58(2)$ & $11.6(3)$ & $0.195(7)$ & $8.0(8)$ & $0.16(2)$ & $21(2)$ & $7.9(6)$ & $1.74(1)$ & $3.0(6)$ & $0.07(1)$ & 100.0 & $13.8(4)$ \\
\hline
\end{tabular}

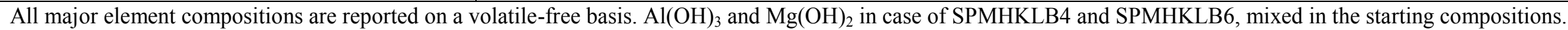

$*=$ Volatile-free composition as reported in Mallik et al (2015); $\dagger=$ Composition as reported in Mallik and Dasgupta (2013,2014).

All oxide and $\mathrm{H}_{2} \mathrm{O}$ concentrations are reported in weight percent. $\mathrm{H}_{2} \mathrm{O}$ concentration is estimated by mass balance.

${ }^{1}$ Melt compositions estimated by electron microprobe; ${ }^{2}$ Melt compositions estimated by LA-ICPMS 
Table 2. Conditions, phase proportions and intrinsic oxygen fugacity estimates for experiments used in this study.

\begin{tabular}{|c|c|c|c|c|c|c|c|c|c|c|c|c|c|}
\hline Exp. No. & $\mathrm{P}(\mathrm{GPa})$ & $\mathrm{T}\left({ }^{\circ} \mathrm{C}\right)$ & Duration (h) & & Melt & $\mathrm{Ol}$ & Opx & Cpx & $\mathrm{Gt}$ & $\mathrm{Phl}$ & $\Sigma \mathrm{r}^{2}$ & Fe-loss & $\Delta \mathrm{fO}_{2}$ \\
\hline \multicolumn{14}{|c|}{4 wt.\% bulk water } \\
\hline \multirow{2}{*}{ B307 } & \multirow{2}{*}{2} & \multirow{2}{*}{1200} & \multirow{2}{*}{93} & EMPA & $0.304(9)$ & $0.058(7)$ & $0.58(1)$ & & & $0.056(8)$ & $0.5(6)$ & $22.0(4)$ & $-1.5(2)$ \\
\hline & & & & LA-ICPMS & $0.241(1)$ & $0.005(5)$ & $0.70(1)$ & & & $0.055(5)$ & $0.5(5)$ & $22.8(6)$ & \\
\hline \multirow{2}{*}{ В309 } & \multirow{2}{*}{2} & \multirow{2}{*}{1250} & \multirow{2}{*}{91} & EMPA & $0.38(2)$ & $0.113(1)$ & $0.50(2)$ & & & & $1.2(6)$ & $6.2(3)$ & $-0.2(3)$ \\
\hline & & & & LA-ICPMS & $0.37(1)$ & $0.082(2)$ & $0.55(1)$ & & & & $0.7(2)$ & $12(2)$ & \\
\hline G358 & 2 & 1300 & 93 & EMPA & $0.53(3)$ & $0.150(6)$ & $0.32(3)$ & & & & $0.6(7)$ & 15 & $-0.4(3)$ \\
\hline \multirow{2}{*}{ G376 } & \multirow{2}{*}{3} & \multirow{2}{*}{1225} & \multirow{2}{*}{90} & EMPA & $0.25(7)$ & $0.02(4)$ & $0.60(5)$ & & + & $0.13(6)$ & $0.3(1)$ & $15(7)$ & $-0.9(3)$ \\
\hline & & & & LA-ICPMS & $0.24(2)$ & + & $0.67(1)$ & & + & $0.065(5)$ & $0.4(1)$ & $8.3(1)$ & \\
\hline \multirow{2}{*}{ G377 } & \multirow{2}{*}{3} & \multirow{2}{*}{1275} & \multirow{2}{*}{52} & EMPA & $0.35(5)$ & + & $0.65(2)$ & & & & $2.8(9)$ & $13(1)$ & $-0.4(3)$ \\
\hline & & & & LA-ICPMS & $0.348(2)$ & + & $0.652(2)$ & & & & $3.0(2)$ & & \\
\hline \multicolumn{14}{|c|}{6 wt. $\%$ bulk water } \\
\hline \multirow{2}{*}{ G379 } & \multirow{2}{*}{2} & \multirow{2}{*}{1200} & \multirow{2}{*}{70} & EMPA & $0.47(8)$ & $0.20(6)$ & $0.33(9)$ & & & & $2.7(5)$ & $9(8)$ & $0.0(2)$ \\
\hline & & & & LA-ICPMS & $0.45(3)$ & $0.15(2)$ & $0.40(6)$ & & & & $1.4(6)$ & $3(5)$ & \\
\hline \multirow{2}{*}{ G380 } & \multirow{2}{*}{2} & \multirow{2}{*}{1250} & \multirow{2}{*}{66} & EMPA & $0.58(7)$ & $0.16(6)$ & $0.26(9)$ & & & & $1.1(3)$ & $5(3)$ & $-0.4(3)$ \\
\hline & & & & LA-ICPMS & $0.61(4)$ & $0.06(3)$ & $0.33(7)$ & & & & $1(2)$ & $4(7)$ & \\
\hline G381 & 3 & 1150 & 77 & EMPA & $0.21(1)$ & $0.04(1)$ & $0.64(2)$ & & & $0.11(2)$ & $0(1)$ & $6(1)$ & $-0.5(2)$ \\
\hline \multirow{2}{*}{ G378 } & \multirow{2}{*}{3} & \multirow{2}{*}{1200} & \multirow{2}{*}{66} & EMPA & $0.38(2)$ & $0.10(1)$ & $0.52(2)$ & & & & $1.3(8)$ & $9.0(1)$ & $-0.6(2)$ \\
\hline & & & & LA-ICPMS & 0.38 & 0.02 & 0.60 & & & & $1.4(6)$ & $4(3)$ & \\
\hline \multirow{2}{*}{ G374 } & 2 & 1250 & 01 & EMPA & $0.43(3)$ & $0.10(4)$ & $0.48(5)$ & & & & $4(4)$ & $7(5)$ & $-1.9(3)$ \\
\hline & 3 & 1250 & 91 & LA-ICPMS & $0.375(9)$ & $0.011(5)$ & $0.61(1)$ & & & & $1.0(3)$ & $-4(4)$ & \\
\hline$C 275$ & 2 & 1200 & 15 & EMPA & $0.460(8)$ & + & $0.54(1)$ & & & & $4.6(9)$ & $40(16)$ & $-0.7(3)$ \\
\hline Sols & 3 & 1500 & $4 J$ & LA-ICPMS & $0.46(2)$ & + & $0.54(2)$ & & & & $2(1)$ & $20(7)$ & \\
\hline
\end{tabular}

Abbreviations used: Ol - Olivine; Opx - Orthopyroxene; Cpx - Clinopyroxene; Gt - Garnet; Phl - Phlogopite.. Phase proportions are reported in weight fraction. $\pm 1 \sigma$ errors are mentioned in brackets and reported as least digits cited, e.g. 0.304(9) to be read as 0.304 \pm 0.009 wt. fraction $\Sigma r^{2}$ - Sum of residual square. Fe-loss indicates the relative Fe-loss to the Au-Pd capsules w.r.t the bulk composition, as estimated by mass balance. $\Delta \mathrm{fO}_{2}$ - Difference between intrinsic oxygen fugacity of experiments estimated by the oxy-barometer of Barr and Grove (2010) and FMQ (fayalite-magnetite-quartz) buffer of O'Neill (1987) and Ballhaus et al. (1991). '+' - Indicates trace presence of a phase which could not be detected by mass balance 
Table 3. $\mathrm{K}_{2} \mathrm{O} / \mathrm{H}_{2} \mathrm{O}$ and $\mathrm{H}_{2} \mathrm{O} / \mathrm{Ce}$ ratios, as well as slab-top temperatures estimated using $\mathrm{K}_{2} \mathrm{O} / \mathrm{H}_{2} \mathrm{O}$ and $\mathrm{H}_{2} \mathrm{O} / \mathrm{Ce}$ ratios (Plank et al., 2009, Cooper et al., 2012)

\begin{tabular}{|c|c|c|c|c|c|}
\hline $\begin{array}{l}\mathrm{H}_{2} \mathrm{O} \text { in sediment } \\
\text { melt (wt.\%) / } \\
\text { Bulk } \mathrm{H}_{2} \mathrm{O} \\
\left(\text { wt.\%) }{ }^{\#}\right.\end{array}$ & $\mathrm{P}(\mathrm{GPa})$ & $\mathrm{K}_{2} \mathrm{O} / \mathrm{H}_{2} \mathrm{O}$ & $\mathrm{T}_{\mathrm{K} 2 \mathrm{O} / \mathrm{H} 2 \mathrm{O}}$ & $\mathrm{H}_{2} \mathrm{O} / \mathrm{Ce}$ & $\mathrm{T}_{\mathrm{H} 2 \mathrm{O} / \mathrm{Ce}}$ \\
\hline \multicolumn{6}{|c|}{ Starting sediment melt compositions } \\
\hline 8 & & 0.73 & 960 & 1818 & 850 \\
\hline 16 & & 0.34 & 880 & 3636 & 790 \\
\hline 24 & & 0.20 & 830 & 5454 & 750 \\
\hline \multicolumn{6}{|c|}{ Experiments with sediment melt and peridotite mixtures* } \\
\hline \multirow{2}{*}{2} & 2 & $0.8(2)$ & $960(32)$ & $1,700(117)$ & $861(7)$ \\
\hline & 3 & $0.6(3)$ & $930(68)$ & $1,800(456)$ & $860(22)$ \\
\hline \multirow{2}{*}{4} & 2 & $0.31(4)$ & $870(12)$ & $3,809(4)$ & $785.9(1)$ \\
\hline & 3 & $0.07(1)$ & $720(22)$ & $3,760(77)$ & $787(2)$ \\
\hline \multirow{2}{*}{6} & 2 & $0.2(1)$ & $840(46)$ & $3,804(1)$ & $786.00(3)$ \\
\hline & 3 & $0.16(8)$ & $800(46)$ & $3,600(461)$ & $790(12)$ \\
\hline \multicolumn{6}{|c|}{ Experiments with sediment melt and peridotite mixtures $\$$} \\
\hline \multirow{2}{*}{4} & 2 & $0.31(6)$ & $870(21)$ & $4,200(542)$ & $780(12)$ \\
\hline & 3 & $0.21(5)$ & $830(25)$ & $3,860(79)$ & $785(2)$ \\
\hline \multirow{2}{*}{6} & 2 & $0.29(2)$ & $865(5)$ & $3,805(2)$ & $785.98(4)$ \\
\hline & 3 & $0.24(8)$ & $840(45)$ & $3,700(560)$ & 790(14) \\
\hline
\end{tabular}

\# - Bulk $\mathrm{H}_{2} \mathrm{O}$ refers to $\mathrm{H}_{2} \mathrm{O}$ concentration in the $25 \%$ sediment-melt and $75 \%$ peridotite mixture used in experiments

Thus, 8 wt. $\% \mathrm{H}_{2} \mathrm{O}$ in the sediment-melt indicates 2 wt. $\%$ bulk $\mathrm{H}_{2} \mathrm{O} ; 16$ wt. $\% \mathrm{H}_{2} \mathrm{O}$ in the sediment-melt indicates 4 wt.\% bulk $\mathrm{H}_{2} \mathrm{O} ; 24$ wt.\% $\mathrm{H}_{2} \mathrm{O}$ in the sediment-melt indicates 6 wt.\% bulk $\mathrm{H}_{2} \mathrm{O}$

* - Melt compositions determined using electron microprobe

$\$$ - Melt compositions determined using LA-ICPMS 


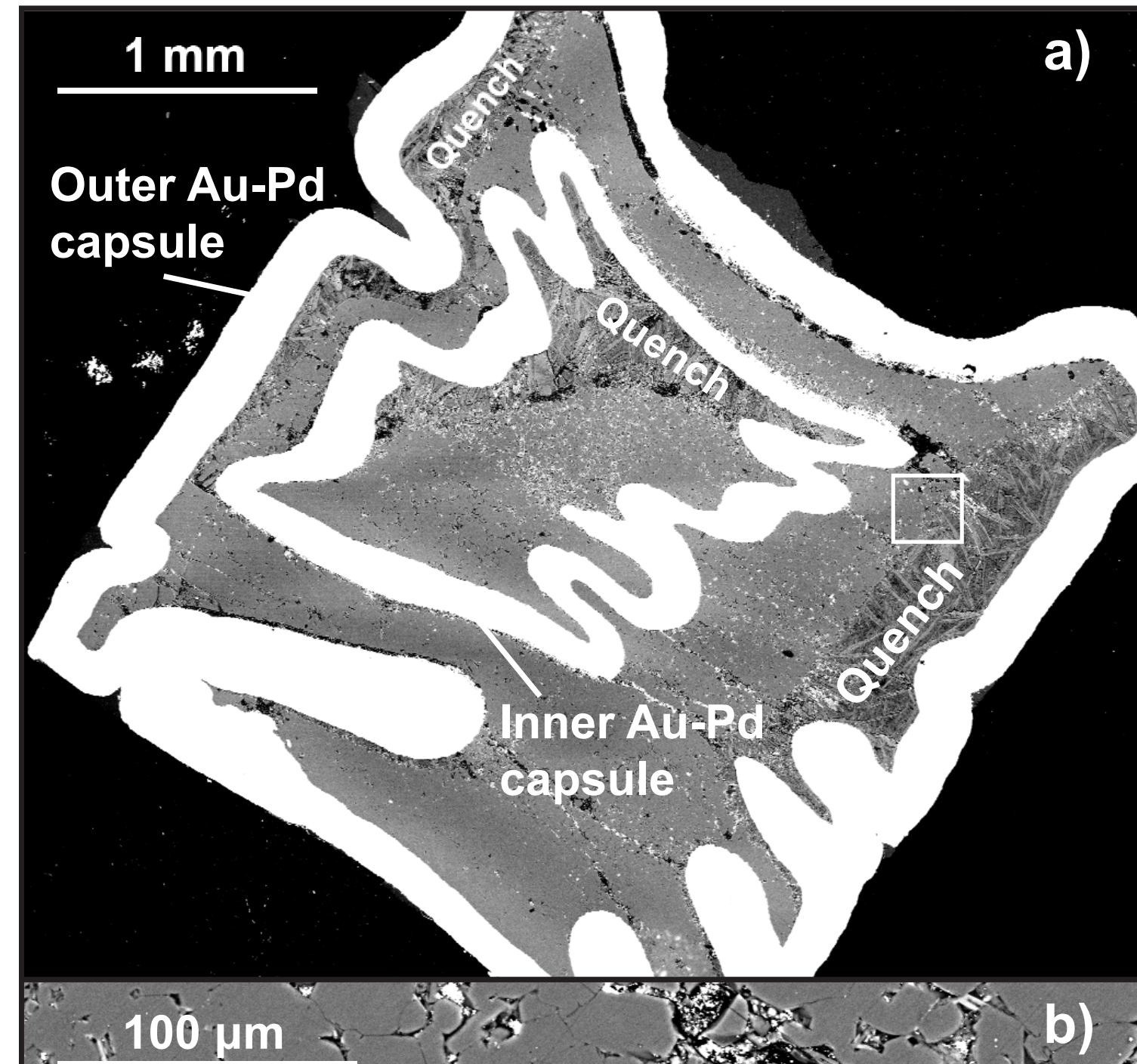

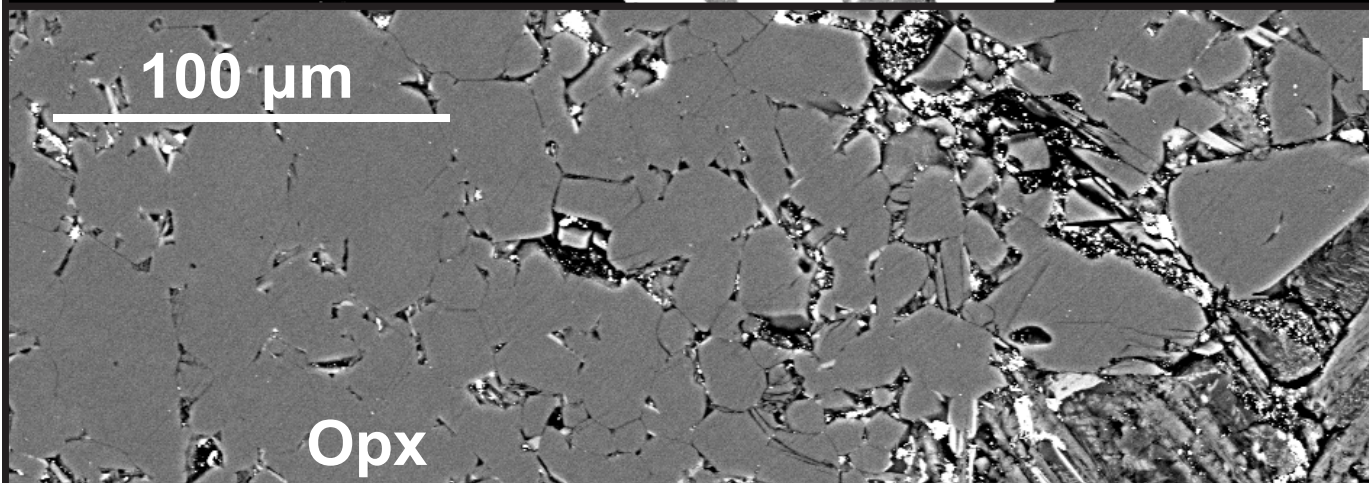

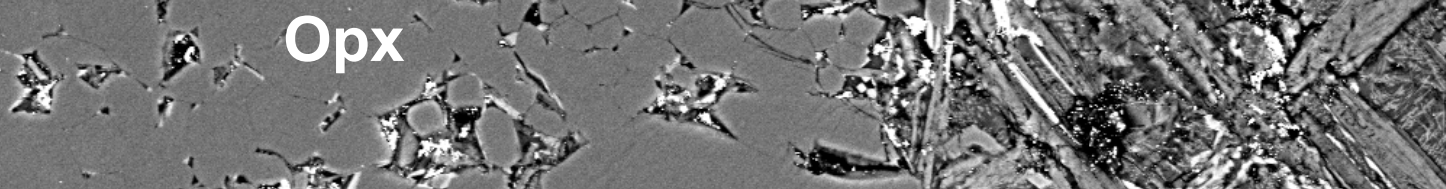
$x-5 x+1$ in

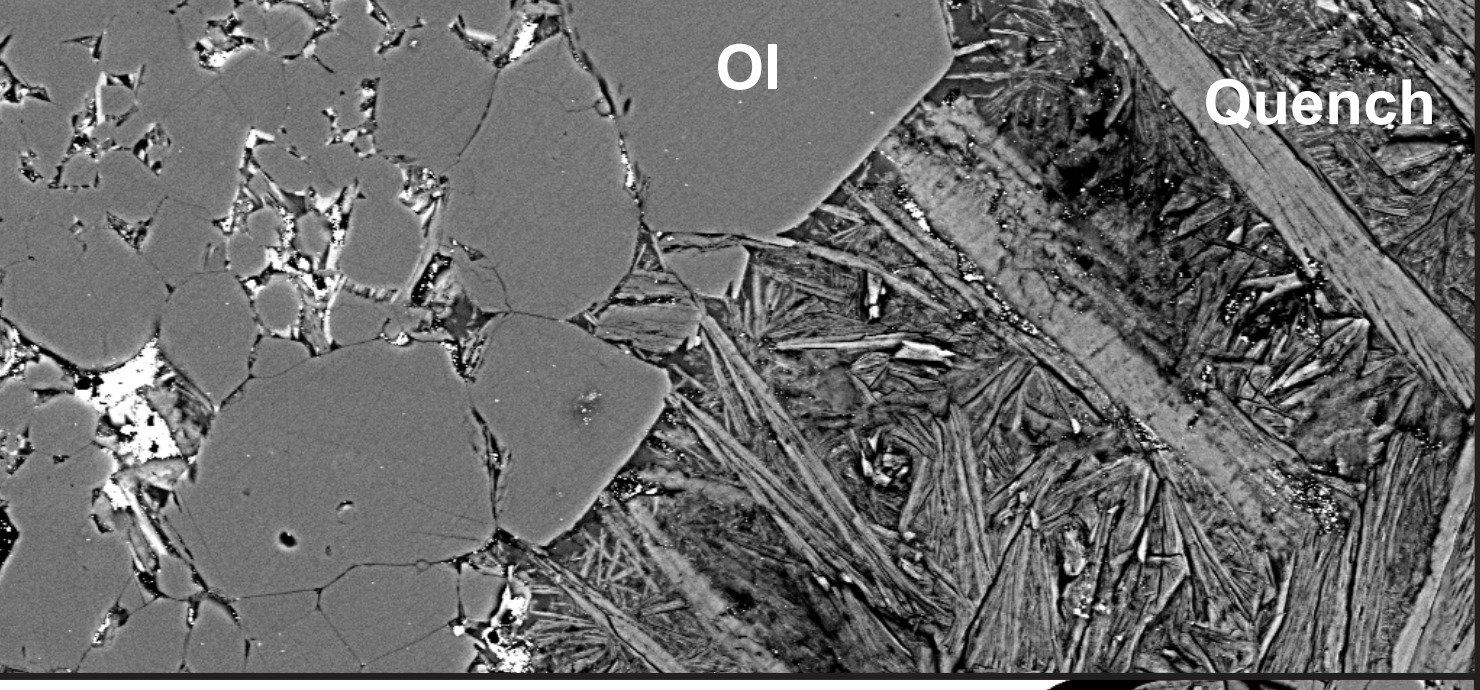
Outer Au-Pd capsule $100 \mu \mathrm{m}$ T.1.

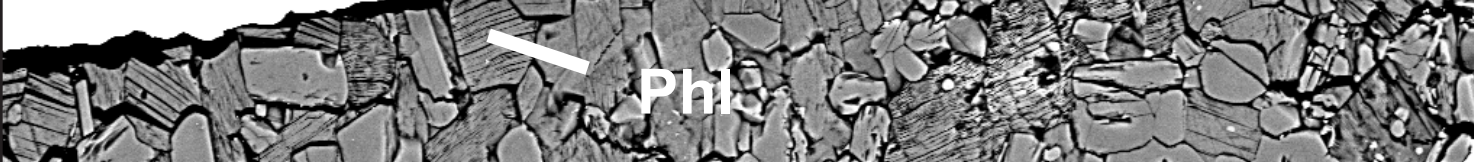

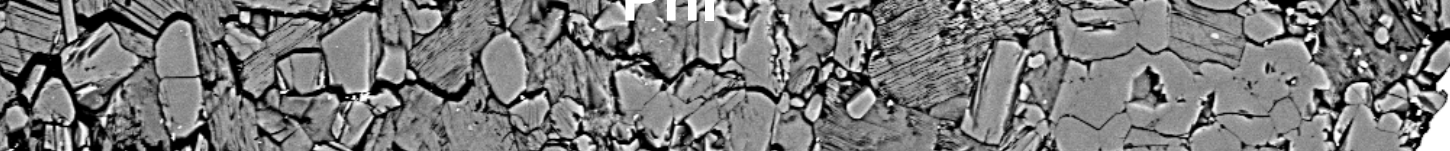

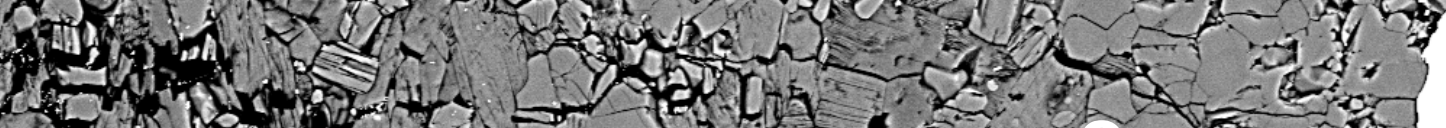

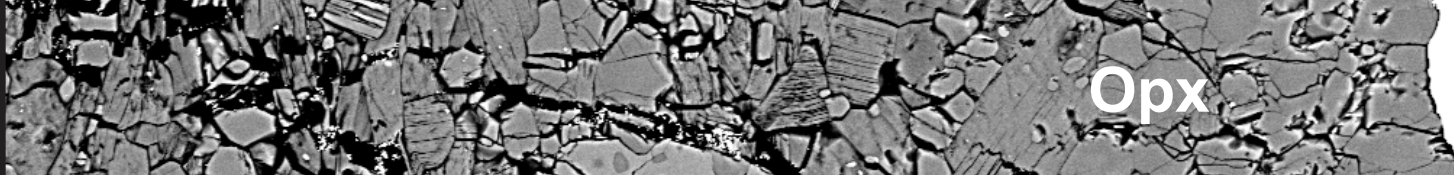

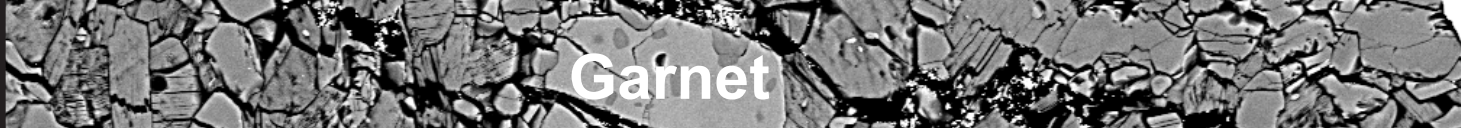

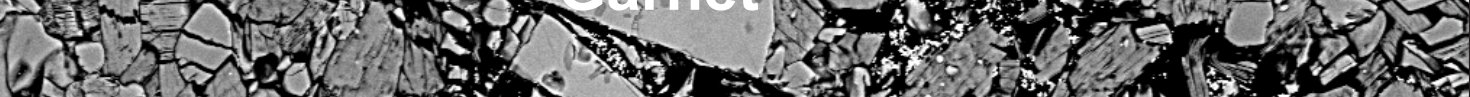

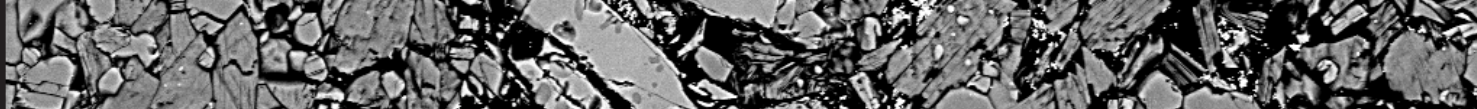

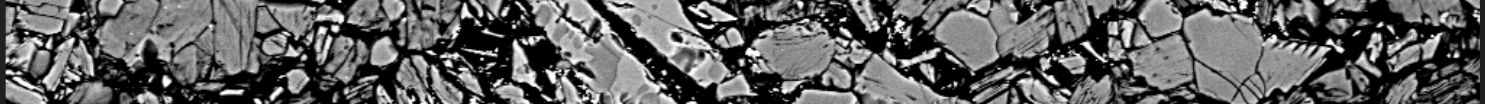

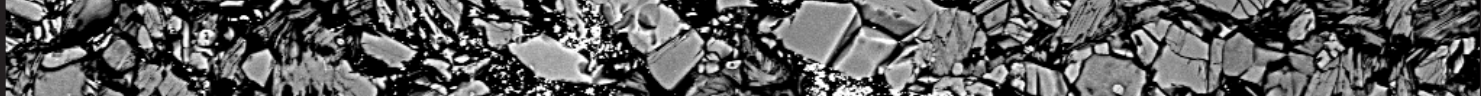

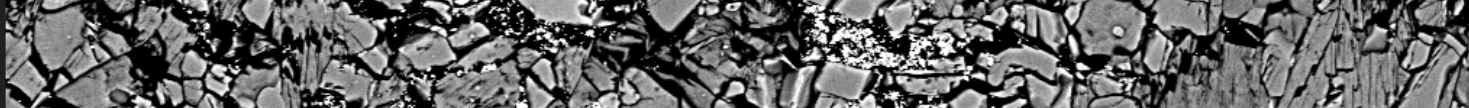

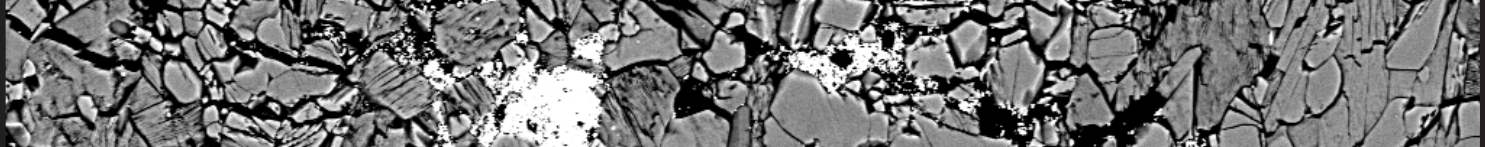
7. 150 , 1 
Figure 2

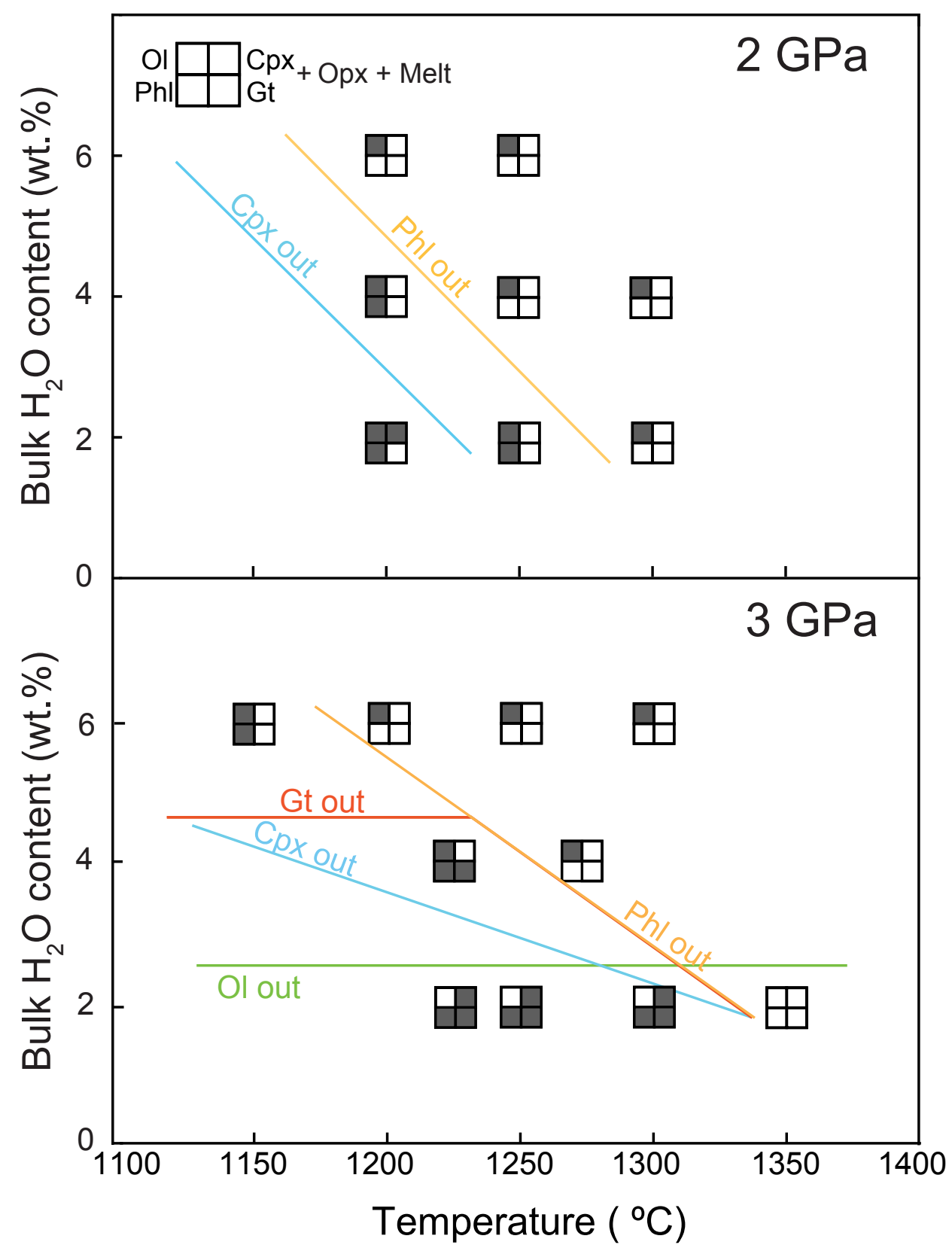




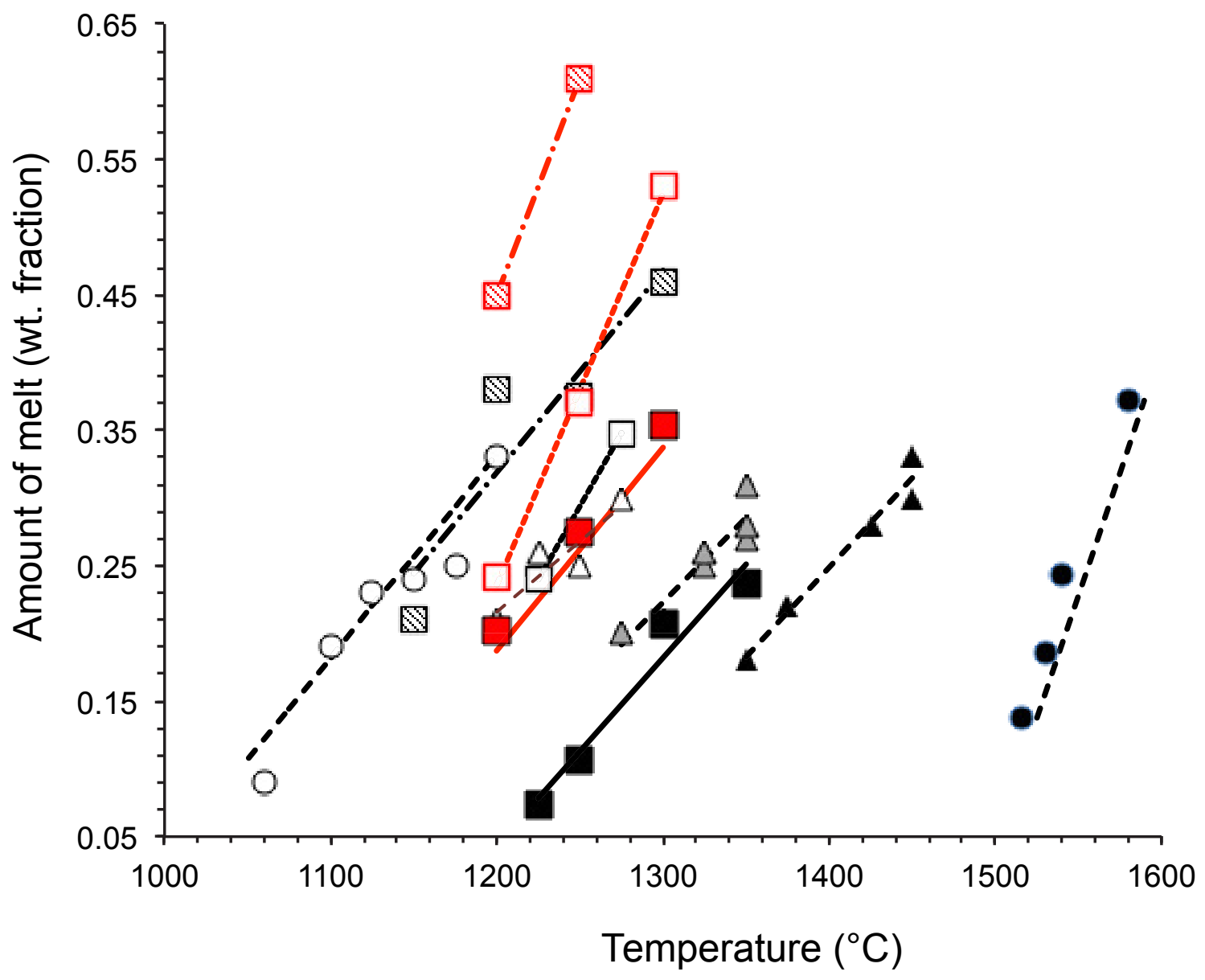

\begin{tabular}{l}
$\square 2$ wt. $\% \mathrm{H}_{2} \mathrm{O}$ \\
$\square 4$ wt. $\% \mathrm{H}_{2} \mathrm{O}$ \\
\hdashline 6 wt. $\% \mathrm{H}_{2} \mathrm{O}$
\end{tabular}$\quad-\begin{aligned} & 2 \mathrm{GPa} \text { (this study, Mallik } \\
& \text { et al. (2015) }\end{aligned}$

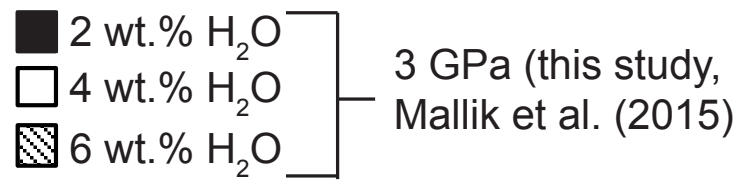

$\begin{array}{ll}\Delta & 1.5 \text { wt. } \% \mathrm{H}_{2} \mathrm{O} \\ \Delta & 2.5 \text { wt. } \% \mathrm{H}_{2} \mathrm{O} \\ \Delta & 5 \text { wt. } \% \mathrm{H}_{2} \mathrm{O}\end{array} \quad \begin{aligned} & \begin{array}{l}\text { Partial melting of } 1.5-5 \\ \text { wt. } \% \mathrm{H}_{2} \mathrm{O}-\text { bearing }\end{array} \\ & \begin{array}{l}\text { peridotite, } 3.5 \mathrm{GPa} \\ \text { (Tenner et al., 2012) }\end{array}\end{aligned}$

Partial melting of 14.5 wt. $\% \mathrm{H}_{2} \mathrm{O}$-bearing peridotite, 3.2 GPa (Till et al., 2012)

- Anhydrous partial melting of peridotite at 3 GPa (Walter, 1998) 
Figure $\rrbracket_{2}$

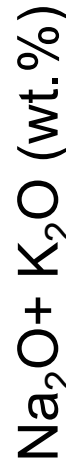

a)
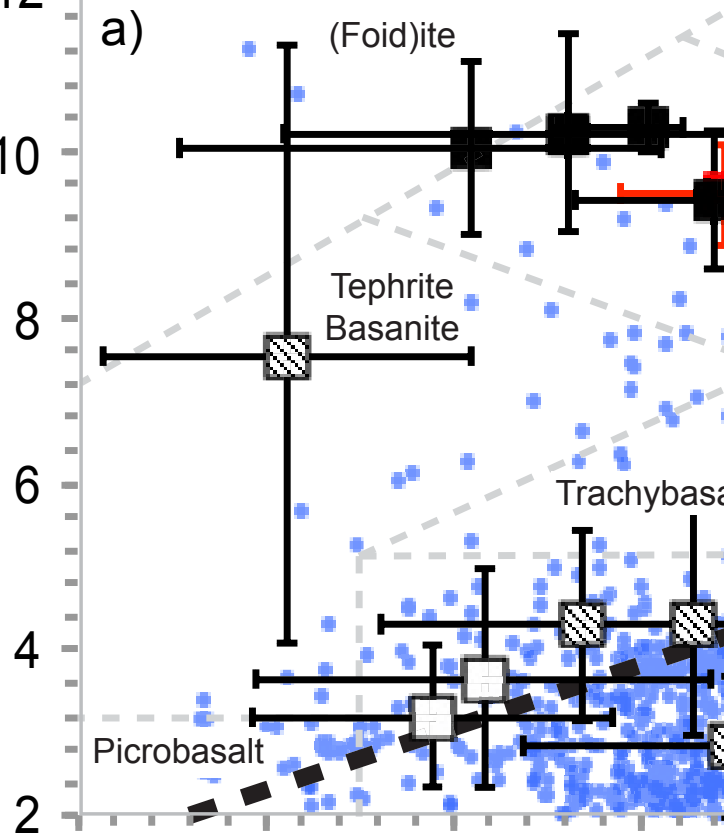

42

44
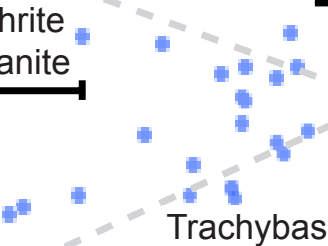

Tephriphonolite

Phonotephrite

Basanite

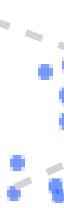

1 trachyandesite

\section{in}
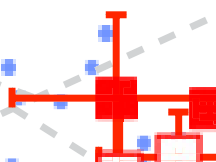

46

48

Basaltic

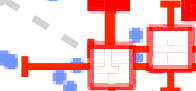

Trachybasalt

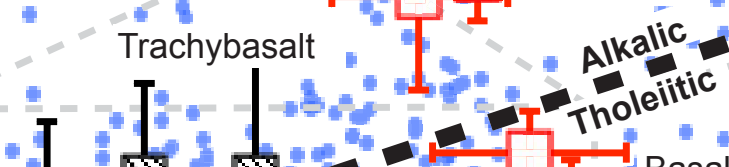

- I 151 Tholeitic

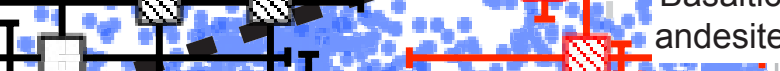
1

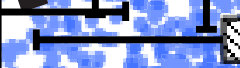

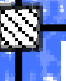

Basalt

$1+1,9$

$\mathrm{SiO}_{2}$ (wt.\%)

50

52

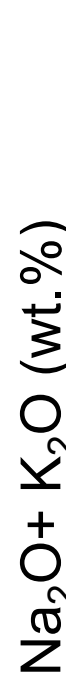

12

b)

10

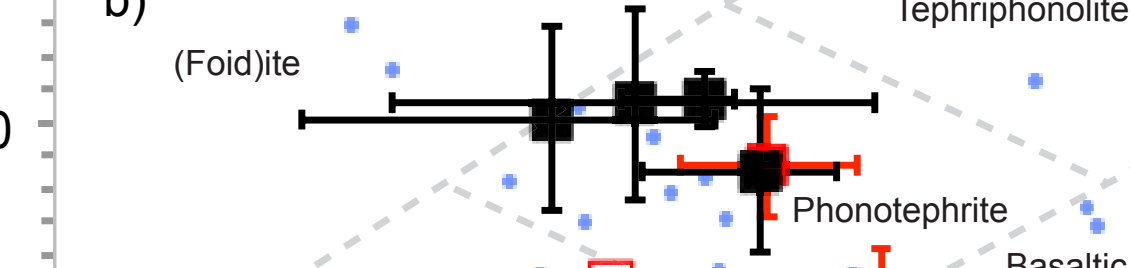

8
6
4

$-1$

Tephrite Basanite

Basaltic

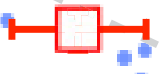

54

Natural arc lavas

2 wt. $\% \mathrm{H}_{2} \mathrm{O}$
$\square 4$ wt. $\% \mathrm{H}_{2} \mathrm{O}$
$\mathrm{\triangle} 6$ wt. $\% \mathrm{H}_{2} \mathrm{O}$

al., 2015) study, Mallik et
4 wt. $\% \mathrm{H}_{2} \mathrm{O}$

S 6 wt. $\% \mathrm{H}_{2} \mathrm{O}$

2015)

$3 \mathrm{GPa}$ (this 
Figure 6

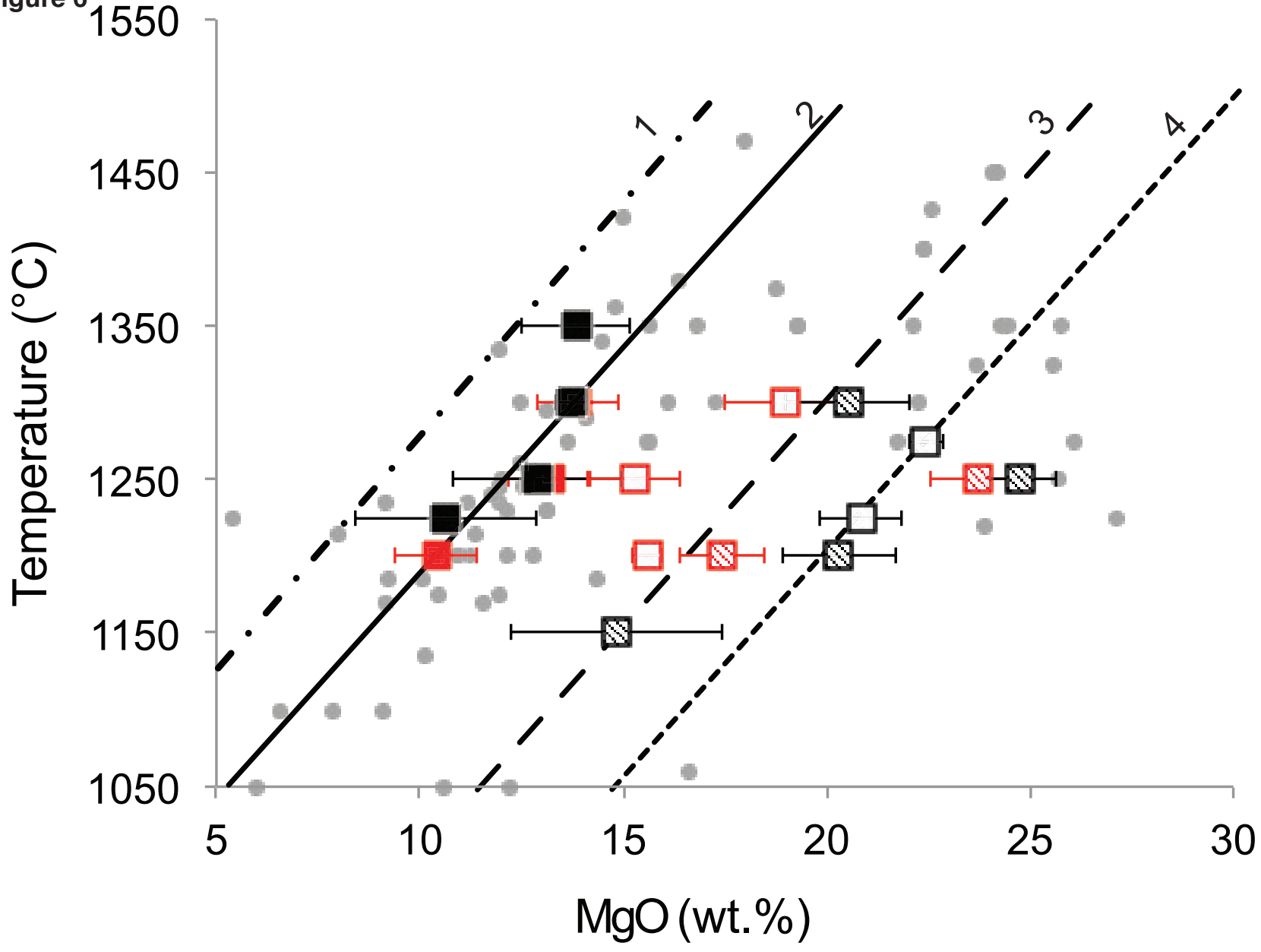

$\square 2$ wt. $\% \mathrm{H}_{2} \mathrm{O}$

$\square 4$ wt. $\% \mathrm{H}_{2} \mathrm{O}$

2 GPa (this study, Mallik

. 6 wt. $\% \mathrm{H}_{2} \mathrm{O}$ et al. (2015)

2 wt. $\% \mathrm{H}_{2} \mathrm{O}$
$\square 4$ wt. $\% \mathrm{H}_{2} \mathrm{O}$
86 wt. $\% \mathrm{H}_{2} \mathrm{O}$

3 GPa (this study,

Mallik et al. (2015)

- Olivine and orthopyroxene saturated hydrous silicate melt compositions from literature 

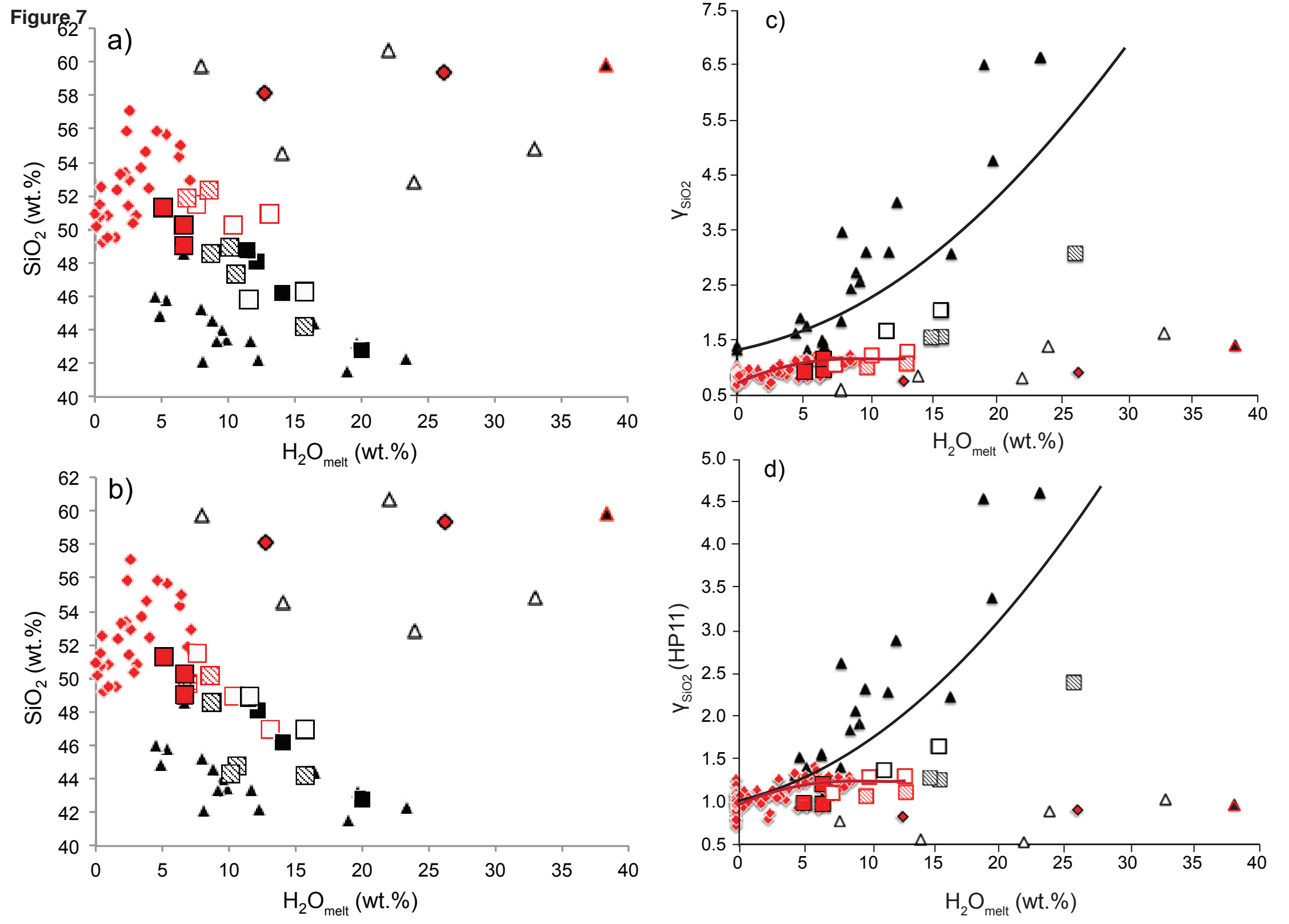

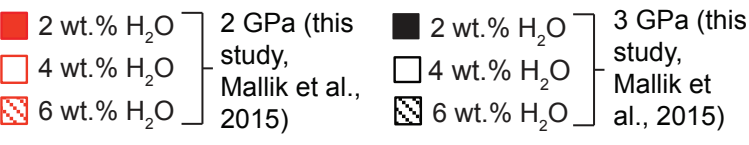

- Melt generated at $\leq 2 \mathrm{GPa}$ $\Delta$ Melt generated at $>2 \mathrm{GPa}$

$\triangle$ Pirard and Hermann (2014 2015), porous flow, $3.5 \mathrm{GPa}$
Melt generated at $\leq 2 \mathrm{GPa}$, with fluid present

A Melt generated at $>2 \mathrm{GPa}$, with fluid present 

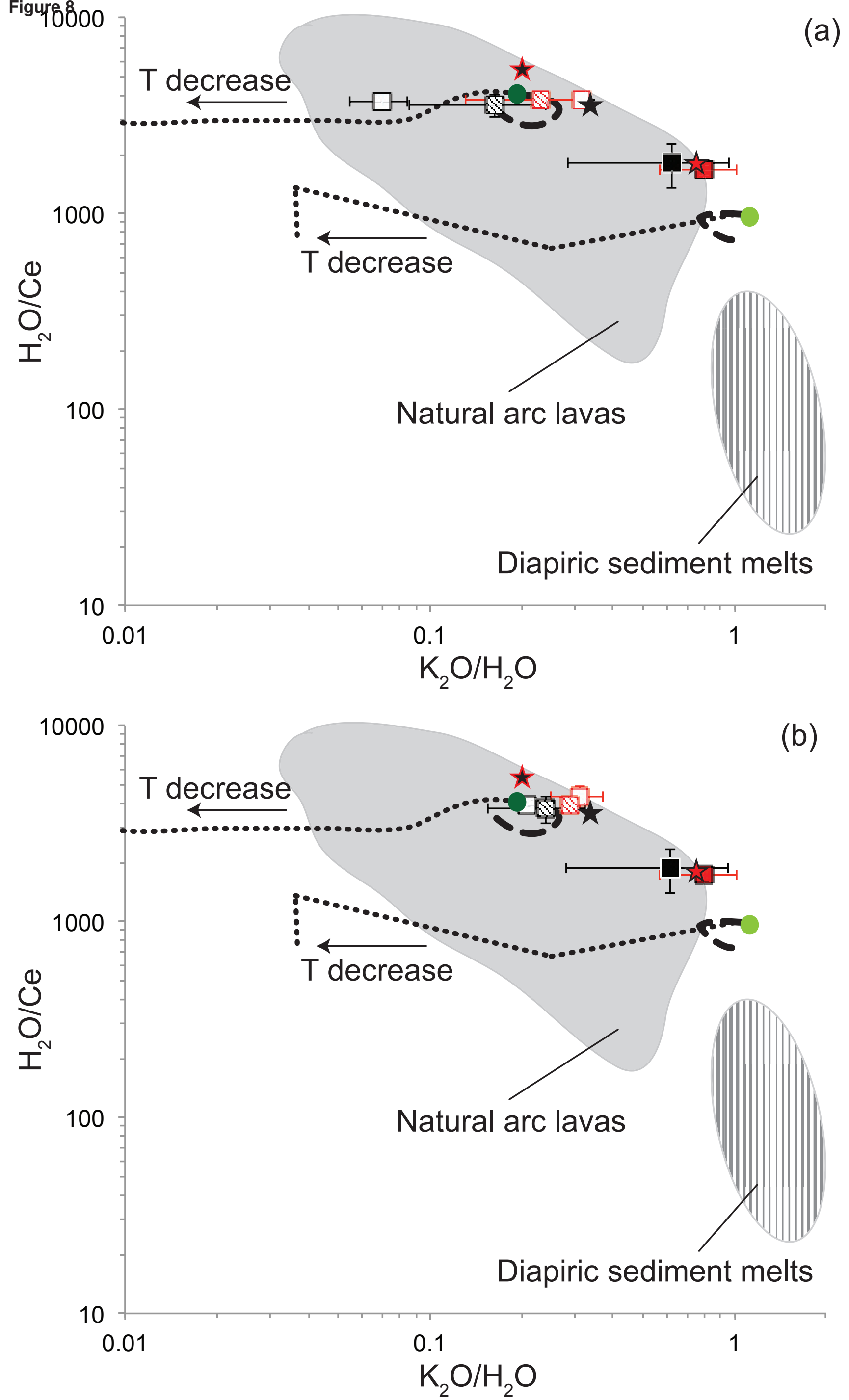

- low-K sediment melt $\quad$ Sediment melt with 8 wt. $\% \mathrm{H}_{2} \mathrm{O}-$ bulk $\mathrm{H}_{2} \mathrm{O}$ ..... Porous flow melt/fluid $\square 2 \mathrm{GPa} \quad 3 \mathrm{GPa}\rfloor 2 \mathrm{wt} . \%$

high-K sediment melt $\quad \star \quad$ Sediment melt with 16 wt. $\% \mathrm{H}_{2} \mathrm{O}$ bulk $\mathrm{H}_{2} \mathrm{O}$ - Focused flow melt/fluid $\square 2 \mathrm{GPa} \quad \square 3 \mathrm{GPa} \quad 4 \mathrm{wt} . \%$

$\star$ Sediment melt with 24 wt. $\left.\% \mathrm{H}_{2} \mathrm{O}\right]$ bulk $\mathrm{H}_{2} \mathrm{O}$ $2 \mathrm{GPa} \quad 3 \mathrm{GPa} \quad 6 \mathrm{wt} . \%$ 


\section{Figure 9}

a)
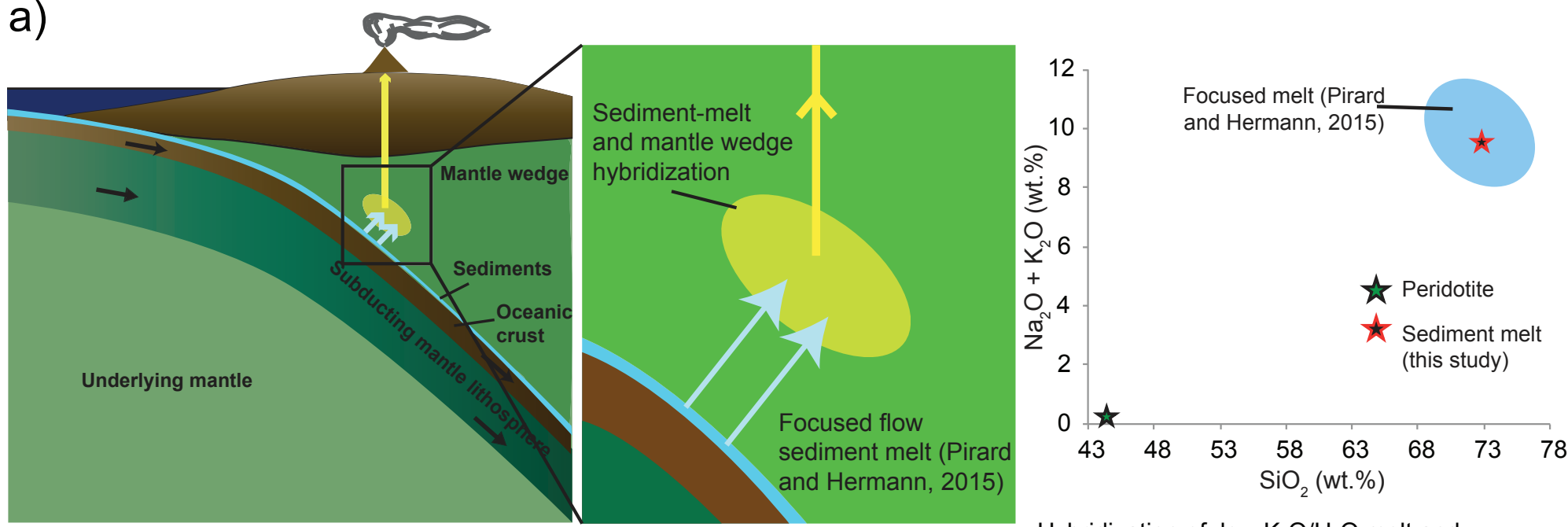

b)

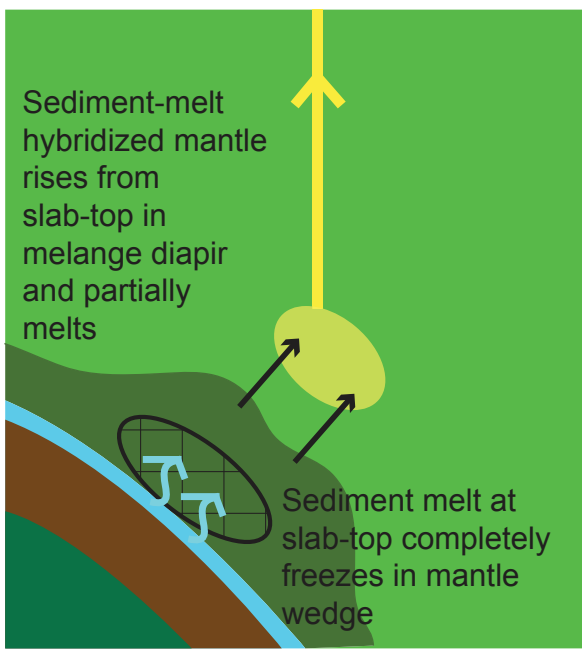

c)

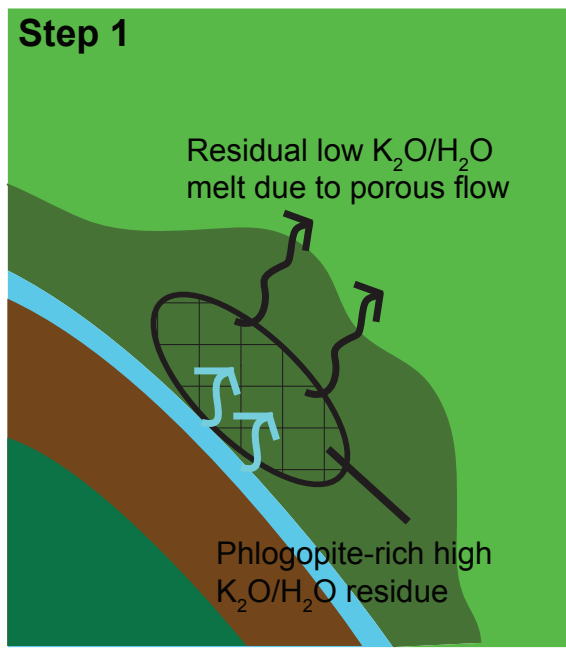

Hybridization of low $\mathrm{K}_{2} \mathrm{O} / \mathrm{H}_{2} \mathrm{O}$ melt and high $\mathrm{K}_{2} \mathrm{O} / \mathrm{H}_{2} \mathrm{O}$ residue. Partial melting of hybridized lithology

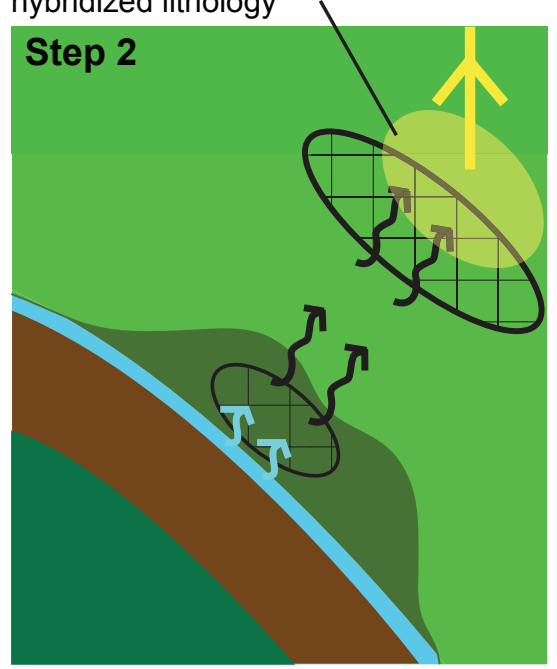

